\title{
Evaluation of the Tubulin-Bound Paclitaxel Conformation: Synthesis, Biology, and SAR Studies of C-4 to C-3' Bridged Paclitaxel Analogues
}

\author{
Thota Ganesh, ${ }^{\dagger}$ Chao Yang, ${ }^{\dagger}$ Andrew Norris, ${ }^{\dagger}$ Tom Glass, ${ }^{\dagger}$ Susan Bane, ${ }^{\ddagger} * *$ Rudravajhala Ravindra, ${ }^{\ddagger}$ Abhijit Banerjee, ${ }^{\ddagger}$ \\ Belhu Metaferia, ${ }^{\dagger}$ Shala L. Thomas, ${ }^{\perp}$ Paraskevi Giannakakou, ${ }^{\perp}$ Ana A. Alcaraz, ${ }^{\S}$ Ami S. Lakdawala, ${ }^{\S}$ James P. Snyder, ${ }^{\S} *$ and \\ David G. I. Kingston ${ }^{\dagger}, *$ \\ Department of Chemistry, M/C 0212, Virginia Polytechnic Institute and State University, Blacksburg, Virginia 24061, Department of \\ Chemistry, State University of New York at Binghamton, Binghamton, New York 13902, Winship Cancer Institute, Emory University School of \\ Medicine, Atlanta, Georgia 30322, and Department of Chemistry, Emory University, Atlanta, Georgia 30322
}

Received September 11, 2006

The important anticancer drug paclitaxel binds to the $\beta$-subunit of the $\alpha \beta$-tubulin dimer in the microtubule in a stoichiometric ratio, promoting microtubule polymerization and stability. The conformation of microtubule-bound drug has been the subject of intense study, and various suggestions have been proposed. In previous work we presented experimental and theoretical evidence that paclitaxel adopts a T-shaped conformation when it is bound to tubulin. In this study we report additional experimental data and calculations that delineate the allowable parameters for effective paclitaxel-tubulin interactions.

\section{Introduction}

The natural product paclitaxel $(\mathrm{PTX})^{a}(\mathbf{1 a})$ and its closely related semisynthetic analogue docetaxel (DTX, 1b) are clinically approved drugs for several tumor malignancies, including breast, lung, and ovarian carcinomas, ${ }^{1}$ while PTX has recently been shown to be effective in reducing the risk of restenosis following percutaneous coronary intervention. ${ }^{2}$ These molecules, in common with several other recently discovered natural products such as the epothilones, ${ }^{3}$ discodermolide, ${ }^{4}$ laulimalide, ${ }^{5}$ and eleutherobin, ${ }^{6}$ act by promoting the polymerization of tubulin to stabilized microtubules, leading to cell cycle arrest at the $\mathrm{G}_{2} / \mathrm{M}$ phase and hence to apoptotic cell death. ${ }^{7-10}$ Although PTX has been shown to influence the phosphorylation and translocation of cell signaling factors, ${ }^{11}$ its clinical activity is believed to be directly related to its microtubule-binding activity. ${ }^{10}$

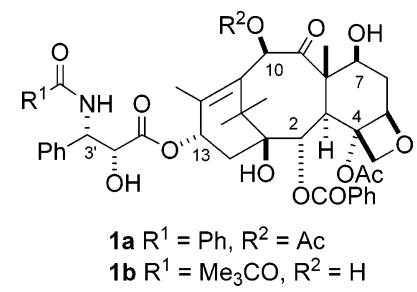

PTX is a complex molecule and is expensive to produce from natural sources. Ideally, future generations of this class of drugs should have much simpler structures, while retaining the activity of the parent drug. Any rational design of improved or simplified analogues would be greatly enhanced by knowledge of the "pharmacophore" of PTX, which can be approximately equated with the conformation of this compound in its binding site on $\beta$-tubulin. Thus the elucidation of this pharmacophore is a matter of great practical as well as theoretical significance.

\footnotetext{
* To whom correspondence should be addressed. Phone: 540-231-6570. Fax: 540-231-3255. E-mail: dkingston@vt.edu.

Virginia Polytechnic Institute and State University.

$\doteqdot$ State University of New York at Binghamton.

$\S$ Department of Chemistry, Emory University.

${ }^{\perp}$ Emory University School of Medicine.

a Abbreviations: PTX, paclitaxel; NAMFIS, NMR analysis of molecular flexibility in solution.
}

The nature of the binding of PTX to tubulin polymer is not yet known in complete detail, although a significant advance was made by the determination of the electron crystallographic structure of $\alpha, \beta$-tubulin, initially at $6.5 \AA$ and later improved to $3.7 \AA .{ }^{12,13}$ Although the latter work was carried out with PTXstabilized zinc-induced sheets, it lacks the resolution to define the detailed conformation of paclitaxel on the tubulin polymer. PTX is a large and conformationally mobile molecule, with rotatable groups at $\mathrm{C}-2, \mathrm{C}-4, \mathrm{C}-10$, and $\mathrm{C}-13$ appended to an essentially rigid tetracyclic ring system. The question of the preferred binding conformation of PTX on the binding site of the tubulin receptor is thus a complicated one.

Previous studies of the bioactive conformation have used evidence from NMR and modeling analyses to suggest three different models for the bioactive conformation of PTX. A "nonpolar" conformation with clustering of the C-2 benzoate and the C-3' benzamido group of the side chain was proposed as the bioactive conformer on the basis of single conformation NMR studies in nonpolar solvents. ${ }^{14-16}$ Similar NMR studies in polar solvents revealed a hydrophobically collapsed conformation with clustering of the C-2 benzoate and the C-3' phenyl group. This led to the proposal that the "polar" conformation is the bioactive form. ${ }^{17-21}$ Although most of the reports assumed a single conformation, deconvolution for PTX in $\mathrm{CDCl}_{3}{ }^{22}$ and $\mathrm{D}_{2} \mathrm{O} / \mathrm{DMSO}-d_{6}{ }^{23}$ makes it clear that the molecule adopts $8-14$ conformations, no one of which achieves a population above $30 \%$. A second approach has used spectroscopic studies of tubulin-bound PTX. One study using REDOR NMR provided $\mathrm{F}-{ }^{13} \mathrm{C}$ distances of 9.8 and $10.3 \AA$ between the fluorine of a 2-(p-fluorobenzoyl)PTX and the C-3' amide carbonyl and C-3' methine carbons, respectively. ${ }^{24} \mathrm{~A}$ related solid-state study employing the NMR RFDR method reported a distance of 5.5 $\AA$ between the fluorines of 2-( $p$-fluorobenzoyl)-3'-( $p$-fluorophenyl)-10-acetyl-DTX. ${ }^{21}$ Both of the latter investigations singled out the polar conformation of PTX as the bound rotamer.

The "polar" and "nonpolar" conformations have inspired a number of elegant synthetic studies designed to generate constrained analogues which maintain these conformations. However, with one exception, ${ }^{25}$ none of the constrained analogues synthesized to date based on these conformations have yielded analogues with both tubulin polymerization and cyto- 
toxic activities equal to or greater than those of PTX itself. Thus, various compounds designed to mimic the polar conformation have been prepared, but these compounds were either inactive ${ }^{26}$ or less active than PTX. ${ }^{27}$ Similarly, constrained analogues based on the nonpolar conformation were also less active than PTX. ${ }^{28-31}$ Two recent studies have presented two bridged taxanes with microtubule stabilizing capacity equivalent to paclitaxel, but with diminished cytotoxicity. ${ }^{32}$ In a review of taxane-bridging strategies, we have detailed the need for a new approach and outlined our initial efforts in this direction. ${ }^{33}$

\section{Results and Discussion}

Design and Development of T-Taxol Models. As outlined above, conception of various bridged analogues as candidates for binding at the taxane site on $\beta$-tubulin followed from hypotheses regarding the nature of the binding pose. In this respect, the T-Taxol conformation is no exception. The groundbreaking work of Nogales, Wolf, and Downing that solved the structure of $\alpha \beta$-tubulin by electron crystallography (EC) was made possible, in part, by stabilizing sheets of polymerized tubulin with zinc cations and PTX. ${ }^{12}$ The $3.7 \AA$ resolution structure, however, was unable to reveal paclitaxel's conformation and binding pose. The molecule's location was nonetheless represented by the single-crystal X-ray structure of docetaxel introduced as a ligand place-holder. ${ }^{34}$ To overcome the paucity of structural detail for the ligand, a strategy combining the lowresolution EC data and higher resolution small molecule structural data was employed.

Specifically, an analysis of the 2D NMR spectra of PTX in both $\mathrm{CDCl}_{3}{ }^{22}$ and $\mathrm{D}_{2} \mathrm{O} / \mathrm{DMSO}-d_{4}{ }^{23}$ using NAMFIS methodology ${ }^{35}$ indicated that the compound adopts over a dozen conformations, among which a T-Taxol or butterfly conformation contributes mole fractions of 0.04 (4\% population) and 0.02 (2\%), respectively, in the two solvents. EC-density fitting of both the NMR conformations and a number of taxane X-ray structures led to the postulate that the T-Taxol conformation is the bioactive form. ${ }^{36}$ This model posits that the centroid of the C-2 benzoate phenyl of PTX is essentially equidistant from the centroids of the phenyl and benzamide-phenyl groups emanating from the $\mathrm{C}-3^{\prime}$ position; thus, the T-shaped conformation. A singular advantage of this structural motif is that when the T-Taxol conformer is nestled into the electron crystallographic density of the PTX-tubulin complex, His227 of the protein is interposed between the $\mathrm{C}-3^{\prime}$ benzamido and C-2 benzoyl phenyl rings of PTX. Hydrophobic collapse of the taxane phenyl groups in this sector of the binding pocket is thereby eliminated as a feature of ligand binding. ${ }^{36}$

Examination of the T-shape shows that the C-3' phenyl and C-4 OAc moieties are juxtaposed, the distance between the $o$-phenyl and methyl centroid hydrogens being only $2.5 \AA$ (Figure 1). ${ }^{37}$ If the T-Taxol model accurately reflects the PTXtubulin interaction, conformationally constrained analogues which maintain this juxtaposition should yield PTX analogues with improved tubulin-binding properties. The entropic penalty resulting from binding to tubulin is greatly reduced in the constrained analogues. As a result these analogues were expected to show a higher bioactivity than PTX itself, particularly when the bridge is short and emanates from the C- $3^{\prime}$ phenyl ortho center. The predictions were vindicated by our preliminary results in this area, which demonstrated that taxoid design and synthesis based on the T-Taxol conformation yields compounds with improved activity in both tubulin polymerization and cytotoxicity assays. ${ }^{37,38}$ Very recently we have presented additional experimental evidence from REDOR NMR and mo-

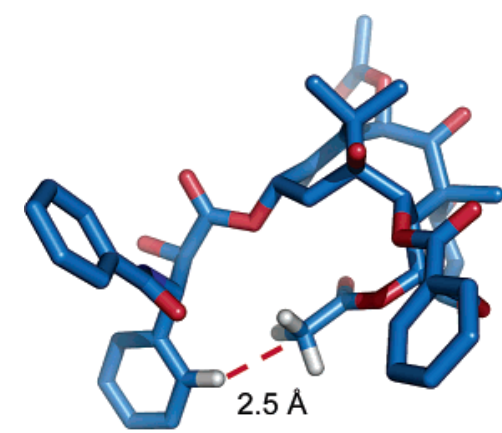

Figure 1. T-Taxol illustrating the short $\mathrm{H}-\mathrm{H}$ distance between the centroid of the C-4 acetate methyl group and the ortho-position of the $\mathrm{C}-3^{\prime}$ phenyl ring.

lecular modeling for the T-Taxol model, ${ }^{39}$ and we have also shown that the model can guide the synthesis of cytotoxic analogues from non-cytotoxic precursors. ${ }^{40}$ In this paper, we describe the synthesis, biological evaluation, and molecular modeling for an expanded set of highly active C-4 to C-3' constrained analogues.

Synthesis of Macrocyclic PTX analogues. We selected the well-established ring-closing metathesis strategy ${ }^{41}$ for the crucial macrocyclization step (Scheme 1), as it has proved highly efficacious for generation of macrocyclic taxoids. ${ }^{27}$ The proposed macrocyclic analogues $(\mathbf{A})$ were envisioned to arise from the open chain $\omega, \omega^{\prime}$-dienes $\mathbf{B}$, which can be derived from modified $\beta$-lactam (C) and baccatin III (D) derivatives.

The retrosynthesis shown in Scheme 1 required the preparation of several $\beta$-lactam derivatives with a substituent at either the ortho or meta position of the phenyl group and various $\mathrm{C}-4$ modified baccatin derivatives. The syntheses of the $\beta$-lactam derivatives were accomplished by application of literature procedures $^{42,43}$ (Scheme 2). The syntheses of $( \pm)$ - $\beta$-lactams $(\mathbf{3} \mathbf{a}-\mathbf{e})$ were achieved starting from 3-allyloxy, 3-vinyl, 2-allyloxy, 2-butenyloxy, and 2-bromo benzaldehydes $(\mathbf{1 a}-\mathbf{e})$ through the $N$-( $p$-methoxy phenyl) (PMP) protected imines $\mathbf{2 a}-$ e. Resolution of the $( \pm)-\beta$-lactams $(\mathbf{3 a}-\mathbf{e})$ was carried out with lipase PS (Amano) to yield the desired enantiomeric acetates $(+)-(\mathbf{4 a}-\mathbf{e})$, along with undesired enantiomeric $(-)$-alcohols (not shown) in more than $95 \%$ yield. ${ }^{43,44}$ Functional group manipulations on $\mathbf{4 a}-\mathbf{e}$ generated the triisopropylsilyl ether intermediates $\mathbf{5 a}-\mathbf{e}$. The 4-(2-bromophenyl) derivative (5e) on Stille coupling ${ }^{45}$ with vinyltributyltin and allyltributyltin produced the 4-(2-vinylphenyl) and 4-(2-allylphenyl) lactam intermediates $\mathbf{5 f}, \mathbf{g}$, respectively. The PMP-protected intermediates $\mathbf{5 a}-\mathbf{d}$ and $\mathbf{5 f}, \mathbf{g}$ were deprotected with ceric ammonium nitrate to produce secondary amides $(\mathbf{6 a}-\mathbf{d}, \mathbf{f}, \mathbf{g})$, which were treated with benzoyl chloride in the presence of triethylamine and dimethylaminopyridine to result in the $(+)-(3 R, 4 S)-1$-benzoyl3-triisopropylsilyloxy-4-(aryl)-azetidin-2-ones $\mathbf{7 a - d}$ and 7f,g. (Scheme 2)

Synthesis of the baccatin derivatives $\mathbf{1 1 a}-\mathbf{d}$ started with the known 4-deacetylbaccatin derivative $8 .{ }^{46}$ Initial attempts to acylate the hindered C-4 hydroxy group using the DCC/DMAP method resulted in unacceptable yields of $\mathrm{C}-4$ acyl derivatives, but the use of acid chloride and LiHMDS in THF at $0{ }^{\circ} \mathrm{C}$ gave the $\mathrm{C}-4$ acyl baccatin derivatives $9 \mathbf{a}-\mathbf{d}$ with yields ranging from 50 to $78 \%$. A minor product acylated at the C-4 position, but with a loss of the 1-dimethylsilyl group, was always obtained in this step, and it was used for the subsequent step. Global deprotection of 9a-d using HF॰pyridine, followed by selective C-10 acetylation ${ }^{47}$ with $0.1 \mathrm{~mol} \%$ of $\mathrm{CeCl}_{3}$ and acetic anhydride in tetrahydrofuran, gave greater than $90 \%$ yields of the desired 10-acetyl derivatives $(\mathbf{1 0 a}-\mathbf{d})$. Selective protection of the C-7 
Scheme 1. Retrosynthetic Logic for Preparation of Macrocyclic Taxanes A from $\omega, \omega^{\prime}$-Dienes B Derived from $\beta$-Lactams $\mathbf{C}$ and Baccatins III D

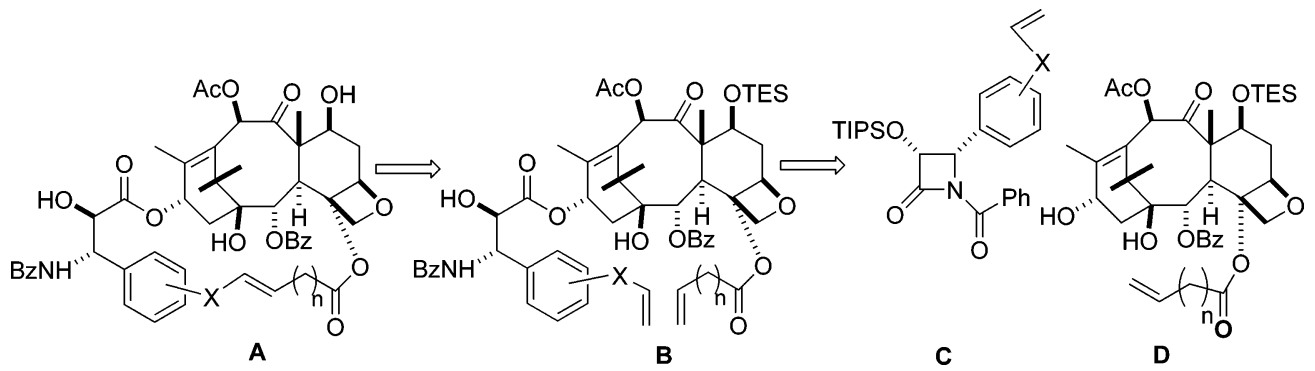

Scheme 2. Synthesis of $\beta$-Lactams $7^{a}$

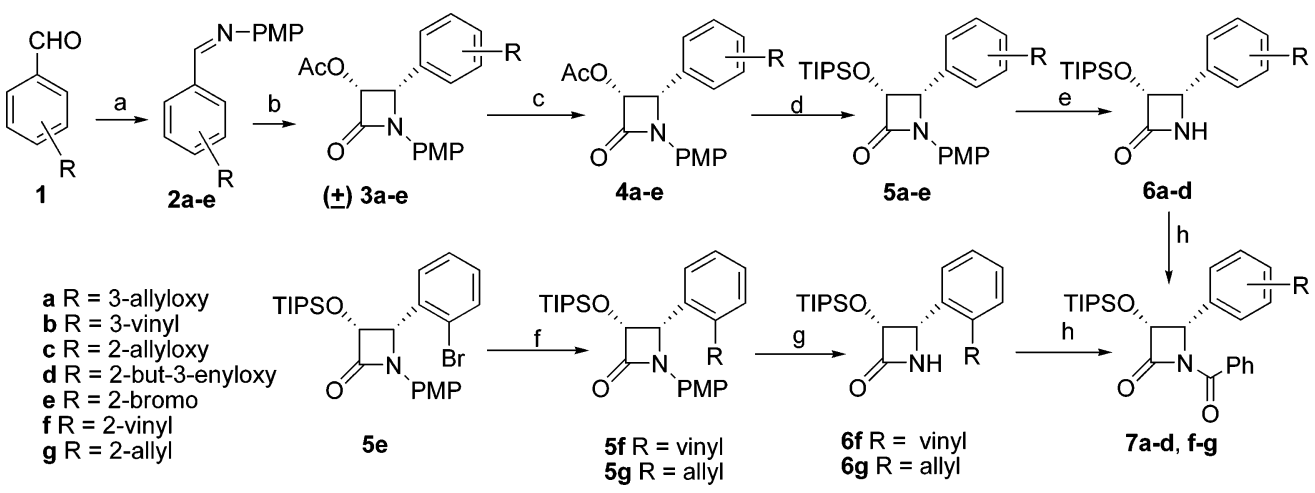

a a. $p-\mathrm{MeOC}_{6} \mathrm{H}_{4} \mathrm{NH}_{2}, \mathrm{MgSO}_{4}, \mathrm{CH}_{2} \mathrm{Cl}_{2}(100 \%)$; b. $\mathrm{CH}_{3} \mathrm{COOCH}_{2} \mathrm{COCl}, \mathrm{Et}_{3} \mathrm{~N}$ or $\mathrm{Pr}_{2}{ }_{2} \mathrm{EtN},-78{ }^{\circ} \mathrm{C}$ to room temp, $12 \mathrm{~h}$ (80-85\%); c. lipase PS (Amano), phosphate buffer, $\mathrm{pH}=7.2, \mathrm{CH}_{3} \mathrm{CN}, 24$ h to $12 \mathrm{~d}(90-95 \%)$ d. i, $1 \mathrm{M}, \mathrm{KOH}, \mathrm{THF}, 0{ }^{\circ} \mathrm{C}$ (quantitative); ii, TIPSCl, imidazole, DMF (90-94\%); e. CAN, $\mathrm{CH}_{3} \mathrm{CN}, 0{ }^{\circ} \mathrm{C}(65-92 \%)$. f. $\mathrm{Pd}_{2}(\mathrm{dba})_{3}, \mathrm{Ph}_{3} \mathrm{P}$, dioxane, $80^{\circ} \mathrm{C}$, vinyltributyltin $(\mathbf{5 f}, 80 \%)$, allyltributyltin $(\mathbf{5 g}, 84 \%)$. g. (i) $\mathrm{CAN} \mathrm{CH}_{3} \mathrm{CN},-5{ }^{\circ} \mathrm{C}(65-70 \%)$. (ii) $\mathrm{PhCOCl}, \mathrm{Et}_{3} \mathrm{~N}, \mathrm{DMAP}, \mathrm{CH}_{2} \mathrm{Cl}_{2}(\mathbf{7 f}, 86 \%$, and $7 \mathbf{g}, 90 \%)$; h. PhCOCl, $\mathrm{Et}_{3} \mathrm{~N}, \mathrm{DMAP}, \mathrm{CH}_{2} \mathrm{Cl}_{2}(85-95 \%)$.

Scheme 3. Synthesis of Baccatins 11a-d ${ }^{a}$

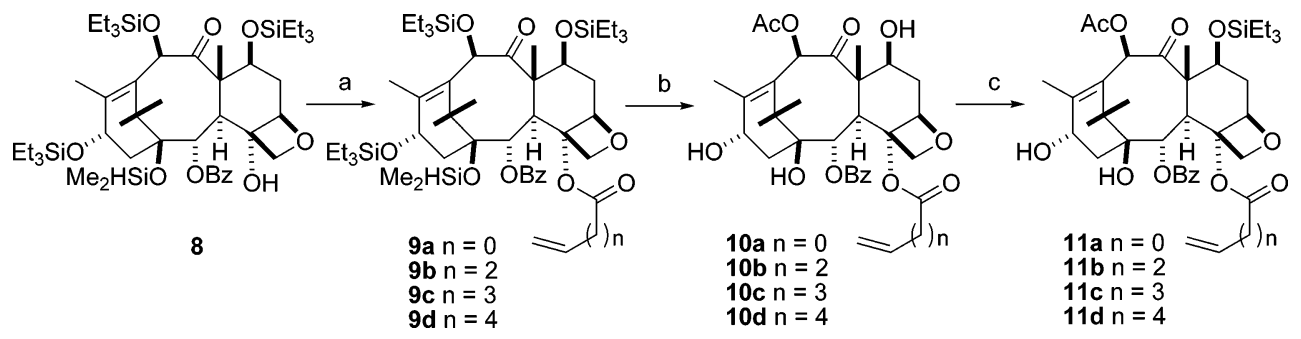

${ }^{a}$ a. LHMDS, THF, $0{ }^{\circ} \mathrm{C}$, acryloyl chloride (9a, 52\%), 4-pentenoyl chloride (9b, 78\%), 5-hexenoyl chloride (9c, 71\%), 6-heptenoyl chloride (9d, 50\%); b. i, HF.Py, THF $(n=0,60 \%, n=2,91 \%, n=3,80 \%, n=4,44 \%)$.ii, $\mathrm{CeCl}_{3}, \mathrm{Ac}_{2} \mathrm{O}, \mathrm{THF}(\mathbf{1 0 a}, n=0,89 \%),(\mathbf{1 0 b}, n=2,92 \%),(\mathbf{1 0 c}, n=3,89 \%)$, $(\mathbf{1 0 d}, n=4,95 \%)$; c. Triethylsilyl chloride, imidazole, DMF $(\mathbf{1 1 a}, n=0,87 \%),(\mathbf{1 1 b}, n=2,85 \%),(\mathbf{1 1 c}, n=3,72 \%),(\mathbf{1 1 d}, n=83 \%)$.

hydroxyl as its triethylsilyl ether afforded the C-4 alkenoyl baccatins 11a-d in good yields (Scheme 3).

Having prepared the desired baccatin III derivatives $(\mathbf{1 1 a}-$ d) and $\beta$-lactam derivatives $(\mathbf{7 a}-\mathbf{d}, \mathbf{f}, \mathbf{g})$, we synthesized the $\omega, \omega^{\prime}$ diene taxoid precursors $\mathbf{1 2 a}-\mathbf{k}$, with yields ranging from 50 to $92 \%$ using the Holton-Ojima coupling protocols ${ }^{48}$ (Scheme 4). These dienes set the stage for the crucial ring-closing metathesis reaction.

Our initial studies of the cyclization reaction employed the $\omega, \omega^{\prime}$-diene substrates $\mathbf{1 2} \mathbf{g}$ and $\mathbf{1 2 h}$ and first generation Grubb's catalyst in dichloromethane under high dilution condition, ${ }^{38}$ but in later studies the second generation Grubbs's catalyst under the same high dilution conditions proved to give superior results. In this particular transformation the open chain diene substrates $\mathbf{1 2 f}-\mathbf{h}$ produce exclusively the $Z$ alkenes $14 \mathbf{f}-\mathbf{h}$, while the dienes $12 \mathrm{a}$ and $\mathbf{1 2 c}$ gave exclusively the $E$-alkenes $\mathbf{1 4 a}$ and $\mathbf{1 4 c}$. The remaining dienes $\mathbf{1 2 d}$ and $\mathbf{1 2} \mathbf{i}-\mathbf{k}$ yielded $E / Z$ mixtures $\mathbf{1 4 d}$, $\mathbf{1 4} \mathbf{i}-\mathbf{k}$ which were separable by silica gel chromatography. All the cyclic derivatives $\mathbf{1 4}$ were subjected to deprotection with $\mathrm{HF} \cdot \mathrm{Py}$ in tetrahydrofuran to produce the bridged paclitaxel analogues $\mathbf{1 5}$ in satisfactory yields. In most cases the more stable
$E$ forms of the bridging double bond were obtained, but for reasons we do not fully understand, only the $Z$ form of compound $\mathbf{1 5 f}$ was obtained. The $Z$ configuration was assigned on the basis of the coupling constant of $11.4 \mathrm{~Hz}$ for the olefinic protons of the bridging double bond. It is noteworthy that compound $\mathbf{2 3}$, with a $m$-methoxybenzoyl group at $\mathrm{C}-2$, gave a mixture of the $Z$-alkene $\mathbf{2 7}$ and the unconjugated $E$-alkene $\mathbf{2 4}$ on olefin metathesis (see below).

In a preliminary effort to explore the absence of $E \mathbf{- 1 5 f}$ from the reactions just described, we carried out density functional theory (DFT) single point calculations on MMFFs $E$ and $Z$ optimized structures (model: B3LYP/6-31G**). Indeed, in contrast to the experimental outcome, the $E$-form is predicted to be more stable than the $Z$-isomer. Preliminary DFT optimization of truncated forms of $Z-\mathbf{1 5 f}$ and $E \mathbf{- 1 5 f}$ provided a similar relative energy. We speculate that the outcome of ring closure metathesis for $\mathbf{1 5 f}$ is not governed by product thermodynamics, but by the geometry of the bulky Grubbs catalyst in complex with the starting diene or the corresponding transition state.

Finally the saturated bridged paclitaxels $\mathbf{1 6}$ were prepared by hydrogenation of $\mathbf{1 5}$ (Scheme 5). It is worth noting here that 
Scheme 4. Synthesis of Bis-Alkenyl Baccatins $13 \mathbf{a}-\mathbf{j}^{a}$
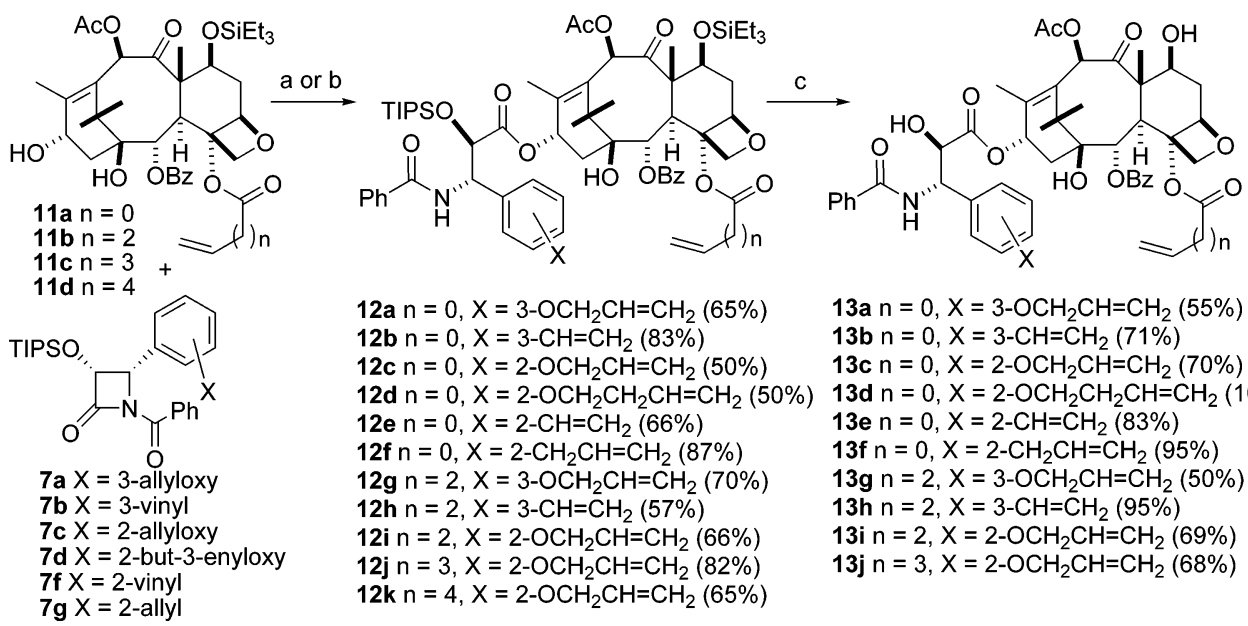

12a $n=0, X=3-\mathrm{OCH}_{2} \mathrm{CH}=\mathrm{CH}_{2}(65 \%)$

12b $\mathbf{n}=0, \mathrm{X}=3-\mathrm{CH}=\mathrm{CH}_{2}(83 \%)$

$12 \mathrm{c} n=0, X=2-\mathrm{OCH}_{2} \mathrm{CH}=\mathrm{CH}_{2}(50 \%)$

$12 \mathrm{~d} n=0, \mathrm{X}=2-\mathrm{OCH}_{2} \mathrm{CH}_{2} \mathrm{CH}=\mathrm{CH}_{2}(50 \%)$

$12 \mathrm{e} n=0, \mathrm{X}=2-\mathrm{CH}=\mathrm{CH}_{2}(66 \%)$

$12 f \mathrm{n}=0, \mathrm{X}=2-\mathrm{CH}_{2} \mathrm{CH}=\mathrm{CH}_{2}(87 \%)$

$12 \mathrm{~g} \mathrm{n}=2, \mathrm{X}=3-\mathrm{OCH}_{2} \mathrm{CH}=\mathrm{CH}_{2}(70 \%)$

$12 \mathrm{~h} \mathrm{n}=2, \mathrm{X}=3-\mathrm{CH}=\mathrm{CH}_{2}(57 \%)$

$12 \mathrm{i} n=2, \mathrm{X}=2-\mathrm{OCH}_{2} \mathrm{CH}=\mathrm{CH}_{2}(66 \%)$

12j $\mathrm{n}=3, \mathrm{X}=2-\mathrm{OCH}_{2} \mathrm{CH}=\mathrm{CH}_{2}(82 \%)$

12k n $=4, \mathrm{X}=2-\mathrm{OCH}_{2} \mathrm{CH}=\mathrm{CH}_{2}(65 \%)$ 13a $\mathrm{n}=0, \mathrm{X}=3-\mathrm{OCH}_{2} \mathrm{CH}=\mathrm{CH}_{2}(55 \%)$

$13 \mathrm{~b} n=0, \mathrm{X}=3-\mathrm{CH}=\mathrm{CH}_{2}(71 \%)$

13c $n=0, X=2-\mathrm{OCH}_{2} \mathrm{CH}=\mathrm{CH}_{2}(70 \%)$

13d $n=0, X=2-\mathrm{OCH}_{2} \mathrm{CH}_{2} \mathrm{CH}=\mathrm{CH}_{2}(100 \%)$

13e $n=0, X=2-\mathrm{CH}=\mathrm{CH}_{2}(83 \%)$

$13 \mathrm{f} n=0, \mathrm{X}=2-\mathrm{CH}_{2} \mathrm{CH}=\mathrm{CH}_{2}(95 \%)$

$13 \mathrm{~g} \mathrm{n}=2, \mathrm{X}=3-\mathrm{OCH}_{2} \mathrm{CH}=\mathrm{CH}_{2}(50 \%)$

$13 \mathrm{~h} \mathrm{n}=2, \mathrm{X}=3-\mathrm{CH}=\mathrm{CH}_{2}(95 \%)$

$13 \mathrm{i} n=2, \mathrm{X}=2-\mathrm{OCH}_{2} \mathrm{CH}=\mathrm{CH}_{2}(69 \%)$

13j $n=3, X=2-\mathrm{OCH}_{2} \mathrm{CH}=\mathrm{CH}_{2}(68 \%)$

${ }^{a}$ a. LHMDS, THF, $-40{ }^{\circ} \mathrm{C}$; b. NaH, THF, $0{ }^{\circ} \mathrm{C}$ to room temp; c. HF·Py in THF, $0{ }^{\circ} \mathrm{C}$ to room temp, $12 \mathrm{~h}$.

neither the dienes $\mathbf{1 2 b}$ and $\mathbf{1 2} \mathbf{e}$ nor their $2^{\prime}, 7$-silyl deprotected derivatives $\mathbf{1 3 b}$ and $\mathbf{1 3} \mathbf{e}$ yielded any of the expected olefin metathesis products $\mathbf{1 4 b}$ and $\mathbf{1 4 e}$ under any of the several ringclosing metathesis conditions tested using either Grubbs catalysts, presumably due to the ring stain inherent in forming the short bridges required for these compounds.

Development of Bridged PTX Analogues with Improved Bioactivities. As pointed out in the introduction, a key test of the proposed bioactive conformations is the synthesis of a constrained analogue that mimics this conformation and possesses an equal or greater bioactivity with respect to the parent compound. In our approach to the synthesis of such a conformationally constrained analogue, we initially synthesized the 21- and 19-membered macrocyclic analogues $\mathbf{1 5 g}$ and $\mathbf{1 5 h}$ with eight and six atoms, respectively, in a bridge between the C-4 acetyl group and the meta-position of the C-3' phenyl group of PTX. ${ }^{38}$ These analogues exhibited modest cytotoxicity against the A2780 ovarian cancer cell line and significant tubulin polymerization (TP) activity, but the activities were considerably less than those of PTX. The reduced activity of $\mathbf{1 5 g}$ was explained by a combination of NMR-NAMFIS analysis, which deconvolutes NMR virtual structures to individual conformers in solution, and a computational analysis of taxane-tubulin complexes. These studies indicated that compound $\mathbf{1 5 g}$, although capable of adopting the bioactive T-form, is seated higher in the PTX-binding pocket as a result of close contact between the propene moiety of the tether and Phe 270 of the protein. ${ }^{38,49}$

In the present study, we initially synthesized the dihydro derivatives $16 \mathrm{~g}$ and $16 \mathrm{~h}$ by hydrogenation of $15 \mathrm{~g}$ and $15 \mathrm{~h}$, respectively, to evaluate whether increased flexibility of alkanebridged macrocyclic taxoids might alleviate the unfavorable interaction with Phe $270 .{ }^{49}$ However, the bioactivities of these compounds with saturated bridges were even less than those of the unsaturated compounds $\mathbf{1 5 g}$ and $\mathbf{1 5 h}$. Surprisingly, the open chain analogues $\mathbf{1 3 g}$ and $\mathbf{1 3 h}$ showed better cytotoxicities than their macrocyclic counterparts $\mathbf{1 5 g}$ and $\mathbf{1 5 h}$ (Table 1).

Molecular modeling studies of the interaction of macrocyclic taxoids linked from the ortho position of the $\mathrm{C}-3^{\prime}$ phenyl group to the $\mathrm{C}-4$ position indicated that these compounds are ideally suited to maintain the T-Taxol conformation while avoiding the unfavorable interaction with Phe270. Thus, these compounds were targeted as especially attractive candidates for synthesis. We adopted a similar ring-closing metathesis strategy to that used for 15g and 15h and subsequently synthesized the ortholinked macrocyclic taxoids $\mathbf{1 5 i}-\mathbf{k}$ and their dihydro derivatives $\mathbf{1 6} \mathbf{i}, \mathbf{j}$ with $8-10$ atoms in the bridge, respectively. These compounds were approximately $10-130$ fold less active than PTX in both cell lines. Interestingly, and in contrast to $\mathbf{1 5 g}$ and $\mathbf{1 5 h}$, the open chain analogues $\mathbf{1 3 i}$,j were found to be inactive or only weakly active against the A2780 cancer cell line (Table 1).

At this point, we investigated the synthesis of compounds with shorter bridges. Thus, the two macrocyclic taxoids $\mathbf{1 5 c}$ and $\mathbf{1 5 d}$ and their saturated dihydro derivatives $\mathbf{1 6 c}$ and $\mathbf{1 6 d}$, with six or seven atoms in the bridge between C-4 and the C-3' $o$-phenyl position of PTX were prepared. The compounds show approximately equal cytotoxicity to PTX against the A2780 ovarian cancer cell line but reduced activity against the PC3 prostate cancer cell line. Comprehensive conformational NMR/ NAMFIS and docking studies indicated that compound 15c was the best fit for the T-conformation of PTX. By modeling, this compound not only seats itself into the tubulin binding pocket, escaping the steric clash observed for meta-bridged compounds $\mathbf{1 5 g}$ and $\mathbf{1 5 h},,^{37,38}$ but it also nicely accommodates His 227 of $\beta$-tubulin, allowing the imidazole ring to insert itself between the stacked rings (cf. Figure 2). ${ }^{37}$

We sought to refine the bridge in $\mathbf{1 5 c}$ further by shrinking the number of connecting atoms. Consequently the 17membered macrocyclic taxoid $\mathbf{1 5 f}$ and its saturated dihydro derivative 16f, with 7 atoms in the bridge linking the ortho position of the C-3' phenyl to the C-4 position, were synthesized. Gratifyingly, the bridged taxoid $\mathbf{1 5 f}$ exhibited excellent bioactivity. It is at least 50 times more potent than PTX against A2780, while its dihydro derivative 16f shows about 30 times more activity than PTX against the same cell line. Both bridged taxoids also show slightly increased cytotoxicity compared with PTX against the PC3 cell line. The unusual activities of $\mathbf{1 5 c}, \mathbf{d}$, 15f, and 16c,d, 16f are not due to the substituents on the C-3' phenyl or the C-4 positions, since the open chain analogues $\mathbf{1 3 c}, \mathbf{d}$ and $\mathbf{1 3 f}$ are almost completely inactive or weakly active against both the A2780 and PC3 cell lines (Table 1). This indicates that the activity associated with the bridged taxoids must originate from their conformational restriction.

Molecular modeling studies suggested that the $E$ bridged macrocyclic analogue of $\mathbf{1 5 f}$ should be more stable than Z-15f, while minireceptor $\mathrm{QSAR}^{50}$ predicts this compound to be more active than PTX. On the basis of these projections, we investigated synthesis of the $E$ macrocyclic bridged derivative of 15f. Subjection of diene $\mathbf{1 2 f}$ to ring-closing metathesis with Grubbs second generation catalyst in dichloromethane at an 
Scheme 5. Synthesis of Bridged Paclitaxels $\mathbf{1 5}$ and $\mathbf{1 6}^{a}$

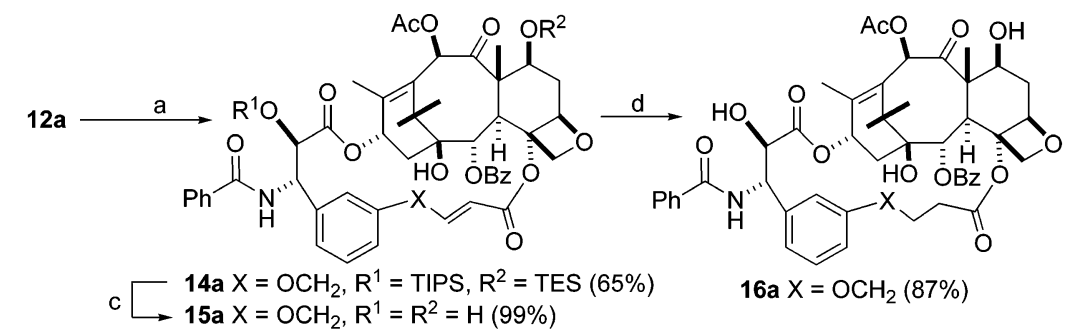

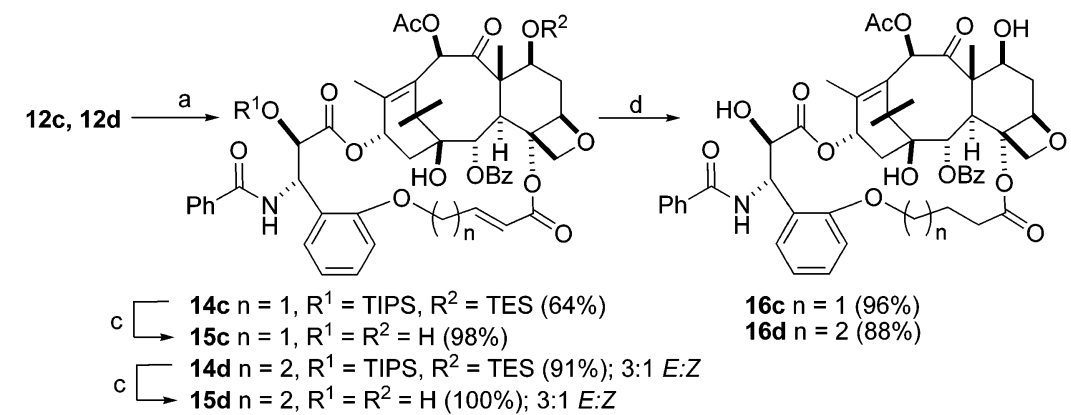

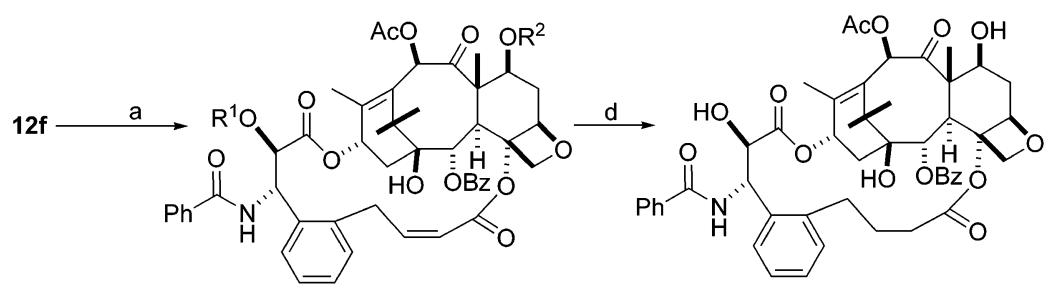

c 14f $R^{1}=$ TIPS, $R^{2}=\operatorname{TES}(87 \%)$

$16 f(62 \%)$

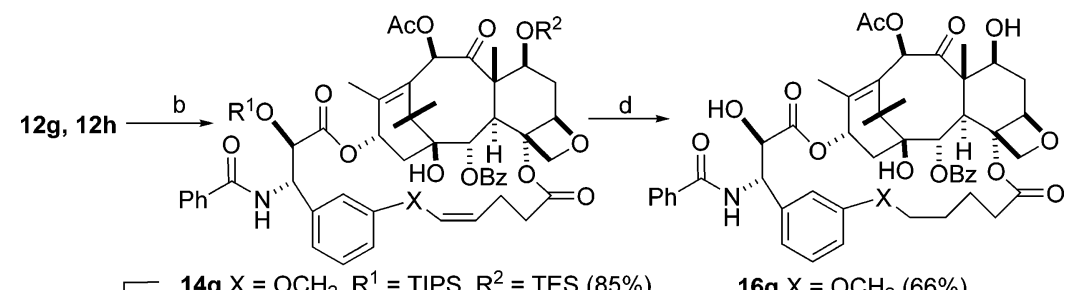

c $-14 \mathbf{g X}=\mathrm{OCH}_{2}, \mathrm{R}^{1}=$ TIPS, $\mathrm{R}^{2}=\mathrm{TES}(85 \%)$

$15 \mathrm{gX}=\mathrm{OCH}_{2}, \mathrm{R}^{1}=\mathrm{R}^{2}=\mathrm{H}(75 \%)$

$16 \mathbf{g X}=\mathrm{OCH}_{2}(66 \%)$

- 14h $X$ absent, $R^{1}=$ TIPS, $R^{2}=$ TES (82\%)

16h X absent (77\%)

c $\longrightarrow 15 \mathrm{~h} X$ absent, $\mathrm{R}^{1}=\mathrm{R}^{2}=\mathrm{H}(70 \%)$
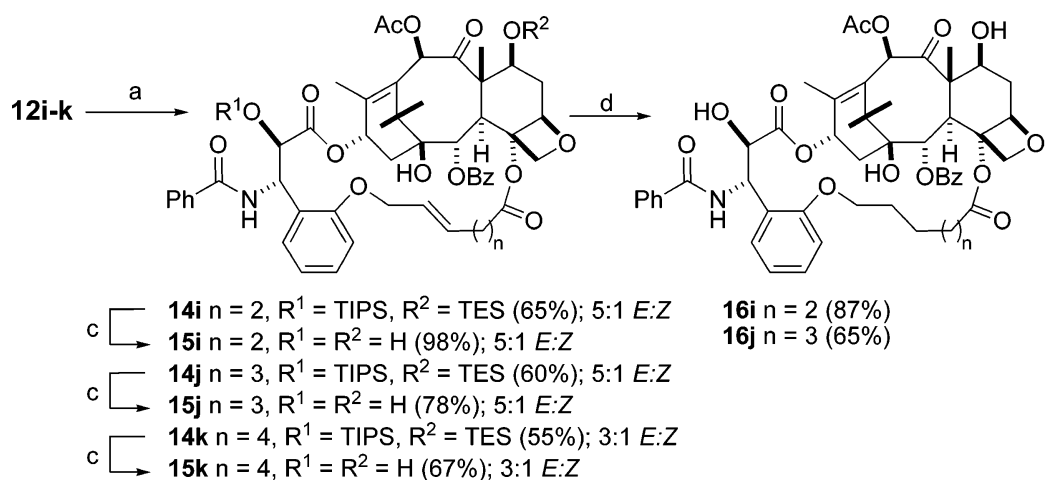

$16 \mathrm{i} n=2(87 \%)$

16j $n=3(65 \%)$

$C \longrightarrow 15 \mathrm{j} \mathrm{n}=3, \mathrm{R}^{1}=\mathrm{R}^{2}=\mathrm{H}(78 \%) ; 5: 1 \mathrm{E:Z}$

c $\square$ 15kn=4, $R^{1}=R^{2}=H(67 \%) ; 3: 1 E: Z$

${ }^{a}$ a. $\left(\mathrm{H}_{2} \mathrm{IMes}\right)(\mathrm{PCy})(\mathrm{Cl})_{2} \mathrm{Ru}=\mathrm{CHPh}, \mathrm{CH}_{2} \mathrm{Cl}_{2}$, room temp; b. $\left(\mathrm{PCy}_{3}\right)_{2}\left(\mathrm{Cl}_{2}\right) \mathrm{Ru}=\mathrm{CHPh}, \mathrm{DCM}$, room temp; c. $\mathrm{HF}, \mathrm{Py}, \mathrm{THF}, 0^{\circ} \mathrm{C}$ to room temp d. $\mathrm{H}_{2}, \mathrm{Pd} / \mathrm{C}$, 35 psi.

elevated temperature of $55^{\circ} \mathrm{C}$ produced exclusively the isomerized product 17f, which on deprotection with HF•Py furnished the isomerized $E$ alkene $\mathbf{1 8 f}$ (Scheme 6). This compound showed excellent cytotoxicity, almost equal to that of the $Z$ bridged derivative 15f, indicating that the precise stereochemistry of the bridging alkene linker causes only a small difference in the activity. The structure of $\mathbf{1 8 f}$ was confirmed by hydrogenation to give a dihydro derivative identical with $\mathbf{1 6 f}$.
Synthesis of Bridged Paclitaxel Derivatives with Modified Pendent Groups. Having optimized the macrocyclic bridge between the C-4 acyl and the C-3' o-phenyl positions, we next investigated the structure-activity relationships at other sites of the bridged paclitaxel analogues in an attempt to identify additional paclitaxel analogues with further improved activity. $\mathrm{We}^{51}$ and others ${ }^{52}$ have previously reported the unusual cytotoxicity and in vitro tubulin polymerization activity of various 
Table 1. Cytotoxicity and Tubulin Polymerization Activity of Macrocyclic and Open Chain Paclitaxel Analogues

\begin{tabular}{|c|c|c|c|}
\hline \multirow[b]{2}{*}{ compound } & \multicolumn{2}{|c|}{$\mathrm{IC}_{50}$ values $(\mathrm{nM})^{a, b}$} & \multirow{2}{*}{$\begin{array}{l}\text { tubulin polym } \\
\left(\mathrm{ED}_{50}, \mu \mathrm{M}\right)^{b, g}\end{array}$} \\
\hline & A2780 & PC3 & \\
\hline PTX & $15^{c}$ & 5 & 0.5 \\
\hline $13 \mathbf{a}$ & 1900 & 550 & 1.0 \\
\hline $13 b$ & 1700 & 320 & 1.0 \\
\hline $13 \mathrm{c}$ & 17800 & $2800^{c}$ & $1.2^{c}$ \\
\hline 13d & 19800 & $>13200$ & $2.7^{c}$ \\
\hline $13 \mathrm{e}$ & $1600^{c}$ & 275 & 1.4 \\
\hline $13 f$ & $1300^{e}$ & 550 & 1.4 \\
\hline $13 \mathrm{~g}$ & $770^{c}$ & 128 & 0.42 \\
\hline $13 \mathrm{~h}$ & 350 & 55 & 0.49 \\
\hline $13 \mathbf{i}$ & 2520 & 2600 & 1.8 \\
\hline $13 \mathbf{j}$ & 7400 & $4600^{c}$ & 2.2 \\
\hline $15 \mathrm{a}$ & 6300 & 580 & $4.6^{c}$ \\
\hline $15 \mathrm{c}$ & 14.5 & 15 & 0.28 \\
\hline 15d & $20^{d}$ & 16 & 0.67 \\
\hline $15 f$ & $0.3^{d}$ & 2.5 & 0.3 \\
\hline $15 \mathrm{~g}$ & 650 & $\mathrm{ND}^{f}$ & $\mathrm{ND}^{f}$ \\
\hline $15 \mathrm{~h}$ & 680 & 34 & 1.6 \\
\hline $15 \mathrm{i}$ & 830 & 55 & 0.9 \\
\hline $15 \mathbf{j}$ & 440 & 90 & 0.53 \\
\hline $15 k$ & $1840^{c}$ & 500 & 0.93 \\
\hline $16 a$ & $700^{d}$ & 53 & 1.4 \\
\hline $16 \mathrm{c}$ & $18.5^{d}$ & $50^{c}$ & 0.83 \\
\hline 16d & 28 & 13 & 0.23 \\
\hline $16 f$ & $0.5^{d}$ & 2.4 & 0.21 \\
\hline $16 \mathrm{~g}$ & $3600^{c}$ & 1000 & $3.4^{c}$ \\
\hline $16 \mathrm{~h}$ & 8800 & 570 & 1.4 \\
\hline $16 \mathrm{i}$ & $980^{c}$ & 51 & 0.76 \\
\hline $16 \mathbf{j}$ & 2000 & $390^{c}$ & 0.85 \\
\hline $18 f$ & $0.5^{d}$ & 3.1 & 0.33 \\
\hline 25 & $23.7^{d}$ & 6 & $0.57^{h}$ \\
\hline 26 & $23.1^{e}$ & $\mathrm{ND}^{f}$ & $\mathrm{ND}^{f}$ \\
\hline 28 & $17.7^{d}$ & 8.2 & $0.22^{h}$ \\
\hline $31 \mathrm{a}$ & $1.4^{d}$ & 3.2 & $0.49^{h}$ \\
\hline 31b & $>6^{i}$ & 11 & $0.35^{h}$ \\
\hline $32 a$ & $0.65^{d}$ & 1.5 & $0.18^{h}$ \\
\hline $32 \mathrm{~b}$ & $0.49^{d}$ & 1.3 & $0.22^{h}$ \\
\hline
\end{tabular}

${ }^{a}$ Average of three determinations unless otherwise stated. ${ }^{b}$ Standard error is less than $10 \%$ of the mean unless otherwise stated. ${ }^{c}$ Standard error between $10 \%$ and $25 \%$ of the mean. ${ }^{d}$ Standard error greater than $25 \%$ of the mean. ${ }^{e}$ Single determination. ${ }^{f}$ ND: Samples were not tested. ${ }^{g} \mathrm{ED}_{50}$ values determined with GTP-tubulin unless otherwise stated. ${ }^{h} \mathrm{ED}_{50}$ values for these samples were determined with GDP-tubulin and were normalized to the GTP-tubulin scale. ${ }^{i}$ The value cited is the lower of two widely different determinations, probably due to solubility problems.

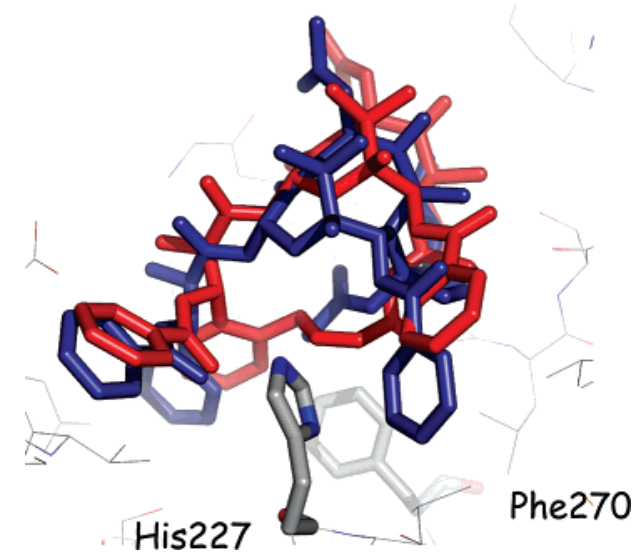

Figure 2. T-Conformations of PTX (blue) and $\mathbf{1 5 f}$ (red) in the $\beta$-tubulin binding site, the latter having been docked by the Glide software. Both conformations were derived by NAMFIS analyses. His 227 is shown in front of the structures, the $\mathbf{1 5 f}$ bridge behind, and Phe270 (ref 49) further behind.

C-2 aroyl-substituted paclitaxel analogues, such as the C-2 $m$-methoxybenzoyl and $m$-azidobenzoyl derivatives. We thus embarked on the synthesis of the C-2 $m$-methoxybenzoyl macrocyclic paclitaxel analogue 28. It was accomplished using modifications of known reactions. Thus 7,10,13-tris(triethylsilyl)-10-deacetylbaccatin (III) 19 was debenzoylated with RedAl followed by protection as its cyclic carbonate $20 .{ }^{27} \mathrm{Com}-$ pound 20 was treated with $m$-methoxyphenyllithium at $0{ }^{\circ} \mathrm{C}$, followed by dimethylsilyl chloride to give $\mathbf{2 1}$ in $70 \%$ overall yield. Finally $\mathbf{2 1}$ was converted to the key intermediate $\mathbf{2 2}$ by steps similar to those of Scheme 2. Coupling of the building blocks $\mathbf{2 2}$ and $\mathbf{7 g}$ under standard conditions ${ }^{48}$ furnished the diene 23 in $70 \%$ yield. Ring-closing metathesis of diene $\mathbf{2 3}$ using second generation Grubbs's catalyst yielded the bridged taxoids 24 and 27 in a 3:1 ratio, with no formation of $E$-alkene. Interestingly, the first generation Grubbs's catalyst failed to bring about macrocyclization under various solvent and temperature conditions. The final compounds $\mathbf{2 5}$ and $\mathbf{2 8}$ were obtained by deprotection with HF.Py in tetrahydrofuran (Scheme 7), while hydrogenation of the two isomers delivered the same saturated compound 26. Disappointingly, the macrocyclic bridged $\mathrm{m}$ methoxy derivative Z-28 and its isomer $\mathbf{2 5}$, both showed reduced activity against the A2780 and PC3 cell lines compared with the corresponding C-2 benzoyl derivative Z-15f, and the dihydro derivative $\mathbf{2 6}$ was also less cytotoxic to the A2780 cell line (it was not tested against the PC 3 cell line). The N-Boc derivatives 31a and 32b were however more promising, and in this series the C-2 $m$-methoxybenzoyl group did not reduce activity significantly in compounds $\mathbf{3 1 a}, \mathbf{3 2} \mathbf{a}$, and $\mathbf{3 2} \mathbf{b}$, in contrast to its effect on the $N$-benzoyl series. The reasons for this difference between the effects of the C-2 $m$-methoxybenzoyl group on the two different series are not clear. It is noteworthy that compounds 32a and 32 $\mathbf{b}$ were the most potent compounds of the entire series against the PC3 cell line and also as promoters of tubulin polymerization.

We then elected to carry out structural modifications on the side chain of the bridged paclitaxel analogues, since docetaxel with an N-Boc substituent has improved activity as compared with PTX. The $\beta$-lactam derivative $7 \mathbf{h}$ was prepared by the procedure described Scheme 2. Coupling of $\mathbf{7 h}$ individually with 11a and 20 gave $\omega, \omega$ '-dienes 29a and 29b, and these dienes upon ring-closing metathesis produced exclusively the cyclic double bond isomerized products $30 \mathbf{a}$ and $30 \mathbf{b}$. None of the normal $Z$ or $E$ unisomerized alkenes were obtained in this reaction. The usual HF•Py deprotection produced the products 31a and 31b, and hydrogenation furnished the dihydro derivatives 32a and 32b (Scheme 8).

The bioactivities of compounds 31a, 32a and 32b were 1030-fold greater than those of PTX in the A2780 cell line, while in the PC3 cell line these compounds were 1.5 to 4 -fold more potent than PTX, and 31b was about half as potent as PTX in this cell line. Since the corresponding PTX analogues $\mathbf{1 5 f}$ and 16f are 30-50-fold more potent than PTX against the A2780 cell line and twice as potent as PTX against the PC3 cell line, it appears that the additional activities generally conferred by the $N$-Boc group and the $m$-methoxybenzoyl group are unique to the unbridged compounds. Modeling suggests a modest reorientation of the terminal phenyl rings in bridged compounds within the taxane binding site. ${ }^{53}$ While the associated binding pose contributes to improved bridge-induced tubulin binding, it apparently dampens these additive substitutent effects at the same time.

Historically, the search for microtubule modifiers has often been accompanied by a preliminary assessment of biological activity by examination of a drug's ability to polymerize tubulin or to influence the stability of microtubules. More recently, this practice has been largely supplanted by a focus on cytotoxicity. 
Scheme 6. Synthesis of Bridged Paclitaxel $\mathbf{1 8}^{a}$

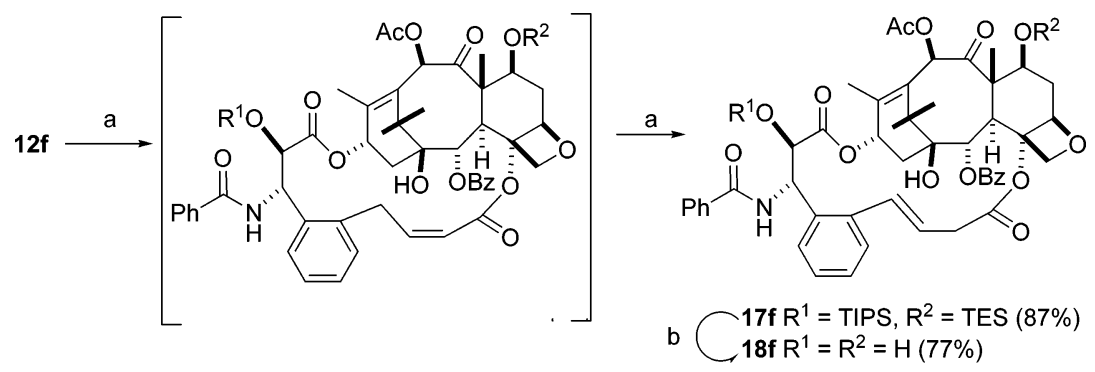

${ }^{a}$ a. Grubbs catalyst, $\mathrm{CH}_{2} \mathrm{Cl}_{2}, 55^{\circ} \mathrm{C}, 77 \%$; b. $\mathrm{HF} / \mathrm{Py}, \mathrm{THF}, 77 \%$.

Scheme 7. Synthesis of Bridged Paclitaxels 25-28

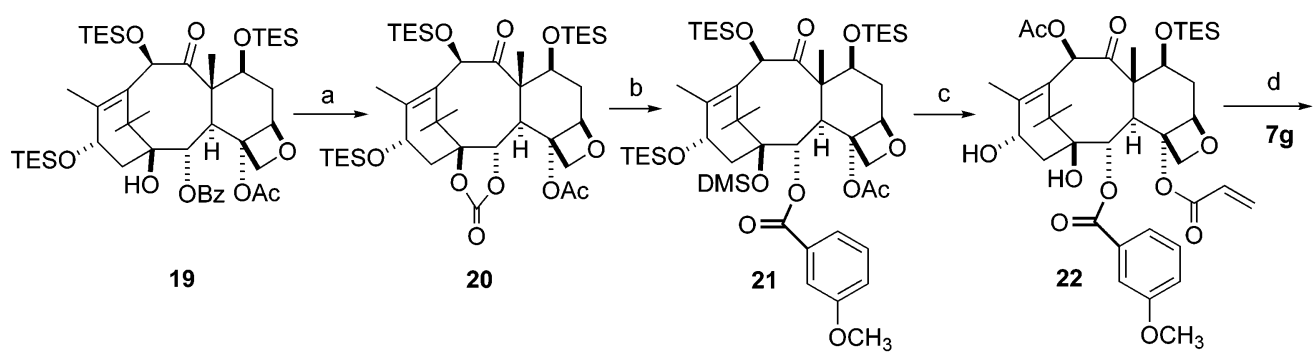

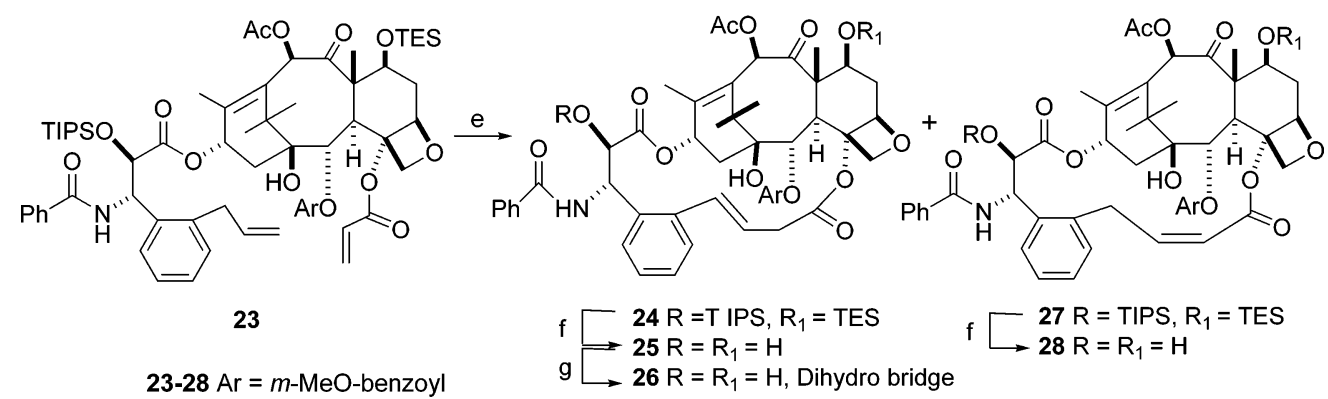

${ }^{a}$ a. i, Red-Al, THF, $0{ }^{\circ} \mathrm{C}$, ii, carbonyldiimidazole, imidazole, 33\% (overal two steps); b. i, $m$-methoxyphenyl- $\mathrm{MgBr}, \mathrm{Et}_{2} \mathrm{O}, 0{ }^{\circ} \mathrm{C}$, ii, $\mathrm{DMSCl}$, imidazole, $70 \%$ (oveal two steps); c. i, Red-Al, THF, $0{ }^{\circ} \mathrm{C}, 55 \%$, ii, LHMDS, $\mathrm{CH}_{2}=\mathrm{CHCOCl}, \mathrm{THF}, 43 \%$, iii, $\mathrm{HF} / \mathrm{Py}, \mathrm{THF}, 0{ }^{\circ} \mathrm{C}$ to room temp, $70 \%$, iv, $\mathrm{Ac} \mathrm{O}_{2} \mathrm{O}, \mathrm{CeCl}{ }_{3}$, THF, room temp, $90 \%$, v, TESCl, imidazole, $\mathrm{CH}_{2} \mathrm{Cl}_{2}, 84 \%$; d. LHMDS, THF, 90\%; e. Grubbs catalyst (2nd), $\mathrm{CH}_{2} \mathrm{Cl}_{2}$, room temp, $70 \%$; f. $\mathrm{HF} / \mathrm{Py}, \mathrm{THF}$, $80 \%$; g. $\mathrm{H}_{2}, \mathrm{Pd} / \mathrm{C}, \mathrm{MeOH}, 60 \%$.

The main reason, of course, is that an effective drug needs to penetrate the membrane of a cell to arrest microtubule function within its boundaries. Factors such as cell permeability, cytoplasmic metabolism, and nonselective binding are, of course, unexamined by an in vitro appraisal of the state of microtubule polymerization. As a consequence, in many cases where both polymerization and cytotoxicity data are available, a correlation fails to emerge. This is the case in the present study. For example, numerous analogues are equal to or within a factor of 2 relative to PTX in the polymerization assay, but 20-1200 fold poorer in the cell-based assays (e.g., 13a, b,c,g,h, $\mathbf{1 5 i} \mathbf{i}, \mathbf{j}$, and $\mathbf{1 6} \mathbf{i}, \mathbf{j})$. By the same token, other in vitro analogues whose activities differ by a factor of 2 from PTX (15c,d, 25, 28, 31a, 32b) are nearly equivalent to PTX in their cellular action. Measurements of critical concentration and $K_{\mathrm{p}}$, the equilibrium constant for polymer growth, would appear to be a much more reliable approach to assessment of biological activity. ${ }^{37}$ Such measurements will be the subject of future work by our laboratories.

Resistance and the Bridged Analogues. An important discovery of the present work is that some of the bridged PTX analogues display promising activity against paclitaxel-resistant and epothilone A-resistant cell lines. The latter were derived by long-term exposure of 1A9 human ovarian carcinoma cells to PTX or epothilone-A (epo-A) in order to generate cells with drug-resistant clones. Subsequent molecular characterization of these clones revealed that the resistance phenotype was due to distinct acquired $\beta$-tubulin mutations at the taxane binding pocket. ${ }^{54,55}$ As a result, PTX's ability to interact with the mutant tubulins in these clones is significantly impaired as evidenced by the lack of drug-induced microtubule-stabilizing activity and essentially lack of G2/M arrest. ${ }^{56}$ Since drug resistance is the factor that hampers most PTX's clinical activity, we set out to test the activity of our analogues against the parental and drugresistant cell lines (Table 2). While $\mathbf{1 3 g}$ and $\mathbf{1 5 c}$ exhibited similar or slightly improved activities over PTX, there are two compounds that stand out. Specifically the bridged taxoid $\mathbf{1 5 f}$ and the dihydro analogue $\mathbf{1 6}$ exhibit a remarkable activity in that not only are they about 100 -fold more active than PTX against the parental 1A9 cells, but they are also 1200- and 150times more effective than PTX (respectively) toward the PTXresistant cell line PTX10 (Table 2). As shown by their relative resistance values, compound $\mathbf{1 5 f}$ is able to completely overcome paclitaxel resistance (1.8 fold) as compared to 20 -fold resistance exhibited by PTX. Compound $\mathbf{1 6 f}$ is able to overcome paclitaxel resistance by $50 \%$, while both compounds are 50 to 90 times more active than PTX against the epothilone-resistant 1A9-A8 cells. The relative potencies of these two compounds are unique.

The relative resistance values (RR) for 1A9-PTX10 cells across the compounds listed in Table 2 range from 2 to 21; those for 1A9-A8, from 3 to 82. The same quantities for $\mathbf{1 5 f}$ and 16f are perfectly normal by comparison, similar to PTX, 
Scheme 8. Synthesis of Bridged Paclitaxels $\mathbf{3 1}$ and $\mathbf{3 2}^{a}$
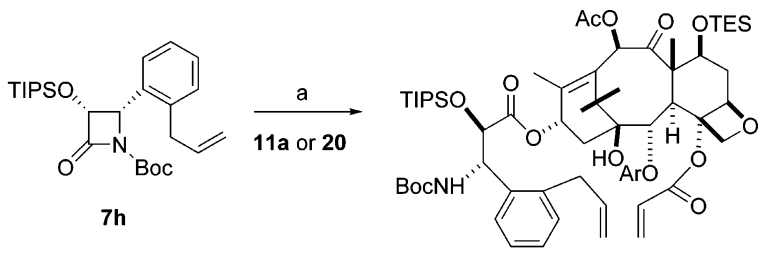

29a $\mathrm{Ar}=$ Benzoyl 29b Ar = m-MeO-benzoyl

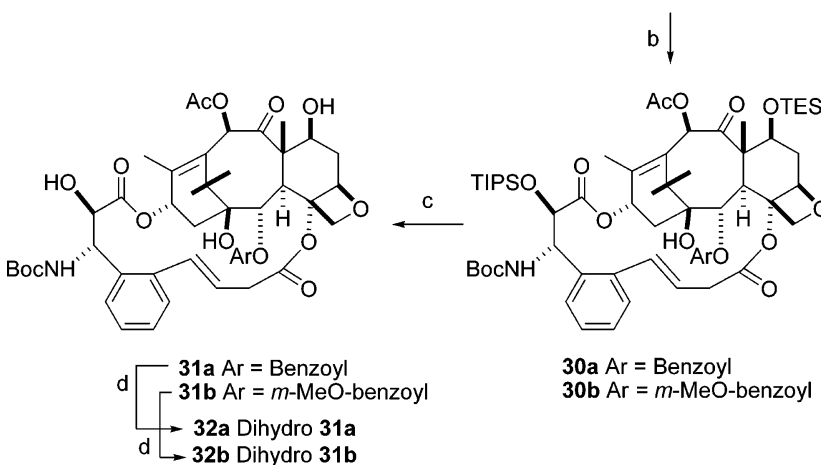

${ }^{a}$ a. LHMDS, THF, 90\%; b. Second generation Grubbs catalyst, $\mathrm{CH}_{2} \mathrm{Cl}_{2}$, RT, 70\%; c. HF/Py, THF, $80 \%$; d. $\mathrm{H}_{2}, \mathrm{Pd} / \mathrm{C}, \mathrm{MeOH}, 60 \%$.

Table 2. Bioactivity of Bridged Taxoids against Paclitaxel and Epothilone A Resistant Cell Lines ${ }^{a}$

\begin{tabular}{|c|c|c|c|c|c|}
\hline \multirow[b]{2}{*}{$\begin{array}{l}\text { bridged } \\
\text { taxanes }\end{array}$} & \multicolumn{2}{|c|}{$\mathrm{IC}_{50}, \mathrm{nM}^{b}$} & \multirow{2}{*}{$\frac{\mathrm{RR}^{c}}{\mathrm{PTX} 10 / 1 \mathrm{~A} 9}$} & \multirow{2}{*}{$\begin{array}{c}\mathrm{IC}_{50}, \mathrm{nM}^{b} \\
1 \mathrm{~A} 9-\mathrm{A} 8 \\
(\mathrm{~T} \beta 274 \mathrm{I})\end{array}$} & \multirow{2}{*}{$\begin{array}{c}\mathrm{RR}^{c} \\
\mathrm{~A} 8 / 1 \mathrm{~A} 9\end{array}$} \\
\hline & 1A9 & $\begin{array}{l}\text { 1A9-PTX10 } \\
(\mathrm{F} \beta 270 \mathrm{~V})\end{array}$ & & & \\
\hline PTX & $4.8 \pm 4.5$ & 157 & 20 & $21.5 \pm 11.5$ & 4.5 \\
\hline $13 \mathrm{~g}$ & $1.8 \pm 2.5$ & 65 & 18 & $148 \pm 67.9$ & 82 \\
\hline 13h & $13.7 \pm 8.6$ & 42 & 5.5 & $137 \pm 28.3$ & 10 \\
\hline $15 c$ & $7.0 \pm 0.85$ & 126 & 17 & $26.5 \pm 3.2$ & 3.8 \\
\hline $15 d$ & $12.2 \pm 7.0$ & 157 & 9.2 & $46.4 \pm 13.6$ & 3.8 \\
\hline $15 f$ & $0.32 \pm 0.35$ & 0.13 & 1.8 & $0.27 \pm 0.08$ & 0.84 \\
\hline $15 \mathrm{~g}$ & $24.6 \pm 9.0$ & 196 & 6.3 & $>300 \pm 0.0$ & $>12$ \\
\hline $15 \mathrm{~h}$ & $12.9 \pm 7.5$ & 157 & 21 & $>300 \pm 0.0$ & $>23$ \\
\hline $16 e$ & $18.9 \pm 1.27$ & 35.9 & 1.8 & $66.5 \pm 5.0$ & 3.5 \\
\hline $16 f$ & $0.07 \pm 0.02$ & 1.03 & 12 & $0.44 \pm 0.19$ & 6.3 \\
\hline
\end{tabular}

${ }^{a}$ 1A9 is the parental drug-sensitive cell line, 1A9-PTX10 is the paclitaxel resistant clone with an acquired F $\beta 270 \mathrm{~V}$ (ref 49) mutation, and 1A9-A8 is the epothilone A resistant clone with an acquired T $\beta 274$ I mutation which also confers cross-resistance to paclitaxel (5-10 times). ${ }^{b} \mathrm{The}_{50} \mathrm{IC}_{50}$ values $(\mathrm{nM})$ for each compound were determined in a 72-h growth inhibition assay using the sulforhodamine-B method as previously described (ref 55). All values represent the average of three or four independent experiments. ${ }^{c} \mathrm{RR}$, relative resistance $=\mathrm{IC}_{50}$ for resistant cell line $/ \mathrm{IC}_{50}$ for parental cell line.

and found in the windows $\mathrm{RR}=0.8-2$ and $6.8-12$, respectively. The implication is that the bridged compounds, from the point of view of acquired resistance, are normal taxanes. The remarkable improvements of $\mathbf{1 5 f}$ and $\mathbf{1 6} \mathbf{f}$ over paclitaxel in apparently overcoming resistance owe their origin to an unusually high potency rather than to subtle structural features of the bridged molecules that enable them to bypass the mutated binding site residues.

Bridged Taxane Conformations in Solution. At the outset of our bridging studies, we hypothesized that creation of short bridges between the ortho-position of C-3' and the methyl of C-4 OAc as depicted in Figure 1 would lead to bioactive conformations in the T-Taxol family and provide highly active taxane analogues. Table 1 provides ample support for the concept and reinforces the proposition that deviations from ortho substitution and short tethers evoke a reduction in both cytotoxicity and tubulin polymerization. It would appear that our initial conformational expectations have been fulfilled. However, we still lack an experimental structure of a bridgedtaxane/tubulin complex and, thus, structural verification of the idea. We note that the two-carbon bridges between the C-3' and $\mathrm{C}-4$ positions now enforce a 17 -membered ring. While the latter involves two lactones, two $\mathrm{C}=\mathrm{C}$ units, and seven bonds rigidified by the baccatin core, it is possible that the newly installed macrocyclic rings might sustain sufficient flexibility to require considerable conformational reorganization upon binding to tubulin. To examine this question, we performed empirical conformational analyses for two of our most active analogues, 15f and 18f. For both compounds, a quantitative NMR-ROESY determination was carried out. The corresponding cross-peaks were translated into intramolecular proton-proton separations based on internal distance standards. The corresponding distances were combined with taxane conformers derived by Monte Carlo conformational analyses within the NAMFIS framework. ${ }^{35}$ As described in numerous previous studies, this technique is able to deconvolute an averaged NMR spectrum into a description of the ensemble of contributing conformations along with an estimate of the individual conformer populations. ${ }^{22,57}$

As applied to $\mathbf{1 5 f}$ with a cis double bond within the bridge, NAMFIS analysis, using 19 NMR-ROE-derived intramolecular atomic distances, delivered five conformations with estimated populations of 40, 27, 17, 9, and 7\% (see Experimental Section). The top populated conformer is the T-form (40\%), while the second and fourth most populated structures (27 and 9\%, respectively) are slightly collapsed forms of the T-conformation in which the $\mathrm{C}^{\prime}$ ' benzamido phenyl to $\mathrm{C} 2$ phenyl centroid distance is $3 \AA$ shorter. The third and fifth structures (17 and $7 \%$, respectively) structures are somewhat extended structures that can be classified as neither $\mathrm{T}$ nor polar forms. Compound $18 f$ delivers a similar result, namely only three conformations from 15 ROE cross-peaks. One is the T-conformation (53\%), the second, a slightly collapsed T-structure (33\%), and the third, the polar conformer (14\%). A similar analysis for parent PTX (1a) delivered T-conformers with much reduced populations of $2-5 \% .{ }^{37}$ Short-bridge ortho-tethering for this compound class increases the concentrations of the apparent bioactive conformers by 5-25 fold and thereby contributes to their exceptional activity. Figure 2 illustrates the superposition of PTX and $\mathbf{1 5 f}$ in the $\beta$-tubulin binding cleft. The conformations of both molecules place the C-3' benzamido and C-2 benzoyl phenyls on either side of His227 (no $\pi$-stacking implied) and simultaneously avoid steric interaction with Phe $270 .{ }^{49}$

\section{Conclusions and Perspectives}

Over the past decade numerous bridging strategies have been explored in the effort to restrain the conformation of the paclitaxel architecture to its bioactive tubulin-bound conformation. Most have led to the synthesis of compounds that are considerably less potent than PTX. ${ }^{33}$ A very few have demonstrated diminished cytotoxicity but matched the latter in a tubulin/microtuble in vitro assay. ${ }^{32}$ Our strategy was directed from the start by analysis of the T-Taxol conformation proposed as the binding geometry of PTX on $\beta$-tubulin. ${ }^{36}$ Significantly, as depicted in Figure 1, it was predicted that a bridge between the methyl group of the C-4 acetate and the ortho-position of the $\mathrm{C}-3^{\prime}$ phenyl group would lead to compounds that are constrained to adopt the bioactive molecular shape.

In the context of activity against A2780 ovarian cancer cells, the synthetic effort has led to seven compounds with activities equal to that of PTX $(\mathbf{1 5 c}, \mathbf{d}, \mathbf{1 6 c}, \mathbf{2 5}, \mathbf{2 6}, \mathbf{2 8}$, and 31a), one that 
is 3-fold more active (32b), three that are 30-fold enhanced (16f, 18f, 31b), and one that shows 50-fold improvement (15f). In the PC3 prostate cell line, the activity enhancements are somewhat less but are still significant (Table 1). Equally important, a subset of these compounds has been tested against both PTX- and epothilone-resistant cell lines (1A9-PTX10 and 1A9-A8, respectively, Table 2). Two of the most active compounds, $\mathbf{1 5 f}$ and 16f, are 1200- and 160-fold more active than PTX with respect to PTX10, respectively, and 90- and 50fold more cytotoxic, respectively, against cells raised against epothilone-resistant cells (A8). Clearly, significant increases in antiproliferative activity can have a dramatic effect on resistance stemming from acquired mutations.

We have examined the origin of the bioactivities by seeking to define the degree of rigidification introduced by the C-4 to C-3' bridging principle. This has taken the form of extracting individual conformations associated with approximate populations from the averaged NMR spectrum of a compound. As applied to unconstrained PTX, the T-form was estimated to be present to the extent of $2-5 \%$ among eight diverse conformations. ${ }^{23,37}$ Constrained compounds $\mathbf{1 5 f}$ and $\mathbf{1 8 f}$, on the other hand, appear in solution as five and three conformations, respectively, with $76 \%$ and $86 \%$ contributions from T-Taxol structures. While the significant activity increases measured for these substances cannot be attributed completely to conformational biasing, the results strongly suggest that this is a dominating factor.

If a given compound adopts the bioactive form, does this guarantee amplified activity? In a recent review of bridged taxanes we pointed out that enforcing the T-Taxol conformation is a necessary but not sufficient condition for eliciting high levels of drug potency. ${ }^{33}$ In addition to the appropriate molecular conformation, the tubulin-taxane ligand must also adopt a compatible molecular volume. Compound $\mathbf{1 5 g}$ with a 5-atom bridge between the meta position of the $\mathrm{C}-3^{\prime}$ phenyl and the C-4 methyl carbon $\left(m-\mathrm{O}-\mathrm{CH}_{2}-\mathrm{CH}=\mathrm{CH}-\mathrm{CH}_{2}\right)$ illustrates the molecular dilemma. Like PTX it displays about $5 \%$ of the T-form in solution. ${ }^{38}$ Unlike PTX, the compound is $4-45$ fold less potent depending on cell line and 10-fold weaker as a tubulin polymerization agent. Modeling demonstrates that a section of the long, suboptimally substituted bridge falls outside the molecular volume of PTX and competes with tubulin's Phe $270^{49}$ for the same space within the binding pocket, as illustrated by Figure 3. Consequently, the ligand either rides higher in the pocket or is pushed out of it. ${ }^{38}$ By contrast, compound $15 \mathbf{c}$ (Table 1$)$ with a three carbon ortho-bridge $(o-$ $\mathrm{O}-\mathrm{CH}_{2}-\mathrm{C}=$ ) likewise presents the T-form in solution, but the truncated bridge avoids a steric clash with the protein and results in activities equivalent to that of PTX. ${ }^{37}$

\section{Experimental Section}

General Experimental Methods. All reagents and solvents received from commercial sources were used without further purification. ${ }^{1} \mathrm{H}$ and ${ }^{13} \mathrm{C}$ NMR spectra were obtained in $\mathrm{CDCl}_{3}$ on Varian Unity or Varian Inova spectrometers at $400 \mathrm{MHz}$ or a JEOL Eclipse spectrometer at $500 \mathrm{MHz}$. High-resolution FAB mass spectra were obtained on a JEOL HX-110 instrument. Specific rotations were measured on a Perkin-Elmer 241 polarimeter. Usual workup was carried out by quenching the reaction, extracting the reaction mixture three times with EtOAc, combining the organic extracts, and washing the combined extracts with $\mathrm{H}_{2} \mathrm{O}$ and brine, followed by drying over $\mathrm{Na}_{2} \mathrm{SO}_{4}$, filtration, and concentration of the organic solution to give crude product. MacroModel v7.2 and Maestro software were obtained from Schrödiner LLC (Portland, OR).

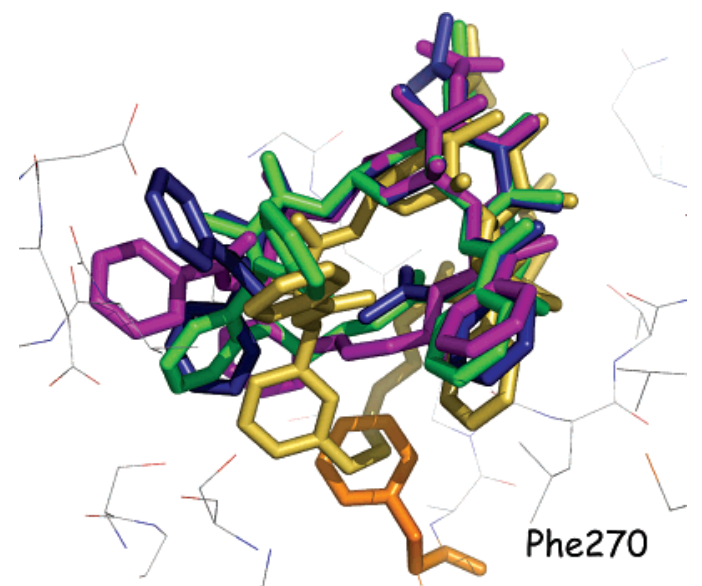

Figure 3. T-Conformation of PTX (blue) bound to $\beta$-tubulin. The T-conformers for the analogues $E-\mathbf{1 5 c}$ (green), Z-15g (yellow), and $E$-18f (magenta) have been derived from NAMFIS analyses. The baccatin cores for PTX and the three analogues are superimposed. The meta-Z-bridged $15 \mathrm{~g}$ (yellow) is pushed out of the taxane binding site because phenylalanine 270 of tubulin (orange) is in steric conflict with the extended bridge, preventing effective binding to the protein. 15c and $\mathbf{1 8 f}$ avoid the Phe270 steric clash and fit nicely into the PTX binding site.

Representative Procedure for the Synthesis of $\beta$-Lactam Derivatives $7 \mathbf{a}-\mathbf{f}$. A typical procedure is described for the synthesis of these $\beta$-lactam derivatives.

(a) Synthesis of Racemic 1-(p-Methoxyphenyl)-3-acetyloxy4-(m-allyloxyphenyl)azetidin-2-one (3a). To a solution of 3-(allyloxy)benzaldehyde (1a, $5 \mathrm{~g}, 34 \mathrm{mmol})$ in $\mathrm{CH}_{2} \mathrm{Cl}_{2}(85 \mathrm{~mL})$ was added $p$-anisidine $(4.38 \mathrm{~g}, 35 \mathrm{mmol})$, followed by $\mathrm{MgSO}_{4}(50 \mathrm{~g}$, in portions), and the resulting reaction mixture was stirred for 12 h. Removal of the $\mathrm{MgSO}_{4}$ by filtration and concentration of the $\mathrm{CH}_{2} \mathrm{Cl}_{2}$ solution yielded crude imine $2 \mathrm{a}(8.5 \mathrm{~g})$. Diisopropylethylamine (100 mmol, 3 equiv) followed by acetoxyacetyl chloride (40 mmol, 1.2 equiv) were added to a solution of $2 \mathbf{a}(8.5 \mathrm{~g}, 33 \mathrm{mmol})$ in $\mathrm{CH}_{2} \mathrm{Cl}_{2}(75 \mathrm{~mL})$ at $-78{ }^{\circ} \mathrm{C}$, and the resulting solution was brought to room temperature over $12 \mathrm{~h}$. The reaction mixture was concentrated, and the residue was purified by chromatography on silica gel using $10-20 \%$ EtOAc in hexane to furnish racemic 1-( $p$ methoxyphenyl)-3-acetyloxy-4-( $m$-allyloxyphenyl)azetidin-2-one (3a, $9.3 \mathrm{~g}, 75 \%$ ).

(b) Resolution of 3a. Lipase PS (Amano) (2 g) was added to a solution of $\mathbf{3 a}(4 \mathrm{~g}, 10 \mathrm{mmol})$ in $\mathrm{CH}_{3} \mathrm{CN}$ and $\mathrm{pH} 7$ phosphate buffer (1:2.5), and the resulting solution was stirred at $\mathrm{rt}$ for $74 \mathrm{~h}$. After usual workup the residue was separated by chromatography on silica gel to furnish $(3 R, 4 S)$-1-methoxyphenyl-3-acetyloxy-4-( $m$-allyloxyphenyl)azetidin-2-one (4a) (1.92 g, 48\%) and $(3 S, 4 R)-1$ methoxyphenyl-3-hydroxy-4-( $m$-allyloxyphenyl)azetidin-2-one (1.84 g, 46\%).

(c) Synthesis of $(3 R, 4 S)$-1-Methoxyphenyl-3-triisopropylsilyloxy-4-( $m$-allyloxyphenyl)-azetidin -2-one (5a). A solution of 4 a (920 mg, $2.5 \mathrm{mmol})$ in tetrahydrofuran $(20 \mathrm{~mL})$ was added dropwise to a stirred solution of $1 \mathrm{M} \mathrm{KOH}(1 \mathrm{M}, 80 \mathrm{~mL})$ and tetrahydrofuran $(20 \mathrm{~mL})$, and the resulting solution was stirred for $15 \mathrm{~min}$. Addition of $\mathrm{H}_{2} \mathrm{O}$ followed by usual workup produced $(3 R, 4 S)$-1-methoxyphenyl-3-hydroxy-4-( $m$-allyloxyphenyl)azetidin-2-one $(800 \mathrm{mg}$, $99 \%)$. To a solution of this alcohol (800 mg, $2.48 \mathrm{mmol})$ in $N, N$ dimethylformamide $(3 \mathrm{~mL})$ was added imidazole $(500 \mathrm{mg}, 7.4$ mmol, 3 equiv) followed by $\operatorname{Pr}_{3}{ }_{3} \mathrm{SiCl}(508 \mathrm{mg}, 2.65 \mathrm{mmol}, 1.1$ equiv), and the resulting solution was stirred at room temperature for $8 \mathrm{~h}$. EtOAc was added to quench the reaction, and the usual workup followed by chromatography over silica gel with $2 \%$ EtOAc in hexane furnished $(3 R, 4 S)$-1-methoxyphenyl-3-triisopropylsilyloxy-4-( $m$-allyloxyphenyl)azetidin-2-one (5a) (1.15 g, 99\%).

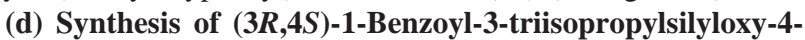
( $\boldsymbol{m}$-allyloxyphenyl)azetidin-2-one (7a). To a solution of 5a (980 $\mathrm{mg}, 2.3 \mathrm{mmol})$ in $\mathrm{CH}_{3} \mathrm{CN}(35 \mathrm{~mL})$ was added ceric ammonium 
nitrate (3.35 g, $6.1 \mathrm{mmol}, 3$ equiv) in $\mathrm{H}_{2} \mathrm{O}(17 \mathrm{~mL})$. The mixture was allowed to stand for $20 \mathrm{~min}$ at $0{ }^{\circ} \mathrm{C}$ and was then stirred for $45 \mathrm{~min}$. EtOAc was added, and the organic phase was washed with saturated sodium metabisulfite. Usual workup followed by chromatography over silica gel with $10 \%$ EtOAc in hexane furnished the imide $(3 R, 4 S)$-3-triisopropylsilyloxy-4-( $m$-allyloxyphenyl)azetidin-2-one (6a, $600 \mathrm{mg}, 78 \%)$. To a solution of $\mathbf{6 a}(568 \mathrm{mg}, 1.5$ mmol) in $\mathrm{CH}_{2} \mathrm{Cl}_{2}(20 \mathrm{~mL})$ were added triethylamine $(0.63 \mathrm{~mL}, 4.5$ mmol, 3 equiv), dimethylaminopyridine $(20 \mathrm{mg})$, and benzoyl chloride $\left(0.52 \mathrm{~mL}, 4.5 \mathrm{mmol}, 3\right.$ equiv) at $0{ }^{\circ} \mathrm{C}$, and the resulting solution was stirred for $1 \mathrm{~h}$. Usual workup followed by chromatography over silica gel with $2-5 \%$ EtOAc furnished $(3 R, 4 S)-1-$ benzoyl-3- $O$-triisopropylsilyloxy-4-( $m$-allyloxyphenyl)azetidin-2one 7a $(600 \mathrm{mg}, 82 \%)$. 7a: $[\alpha]_{\mathrm{D}}+97\left(c=0.4, \mathrm{CHCl}_{3}\right) .{ }^{1} \mathrm{H} \mathrm{NMR}$ $(400 \mathrm{MHz}) \delta=8.02(2 \mathrm{H}, \mathrm{d}, J=7.3 \mathrm{~Hz}), 7.58(1 \mathrm{H}, \mathrm{t}, J=7.3 \mathrm{~Hz})$, $7.47(2 \mathrm{H}, \mathrm{t}, J=7.4 \mathrm{~Hz}), 7.26(1 \mathrm{H}, \mathrm{m}), 6.98(1 \mathrm{H}, \mathrm{d}, J=7.8 \mathrm{~Hz})$, $6.94(1 \mathrm{H}, \mathrm{dd}, J=1.9,1.8 \mathrm{~Hz}), 6.86(1 \mathrm{H}, \mathrm{dd}, J=7.3,2.5 \mathrm{~Hz})$, $6.02(1 \mathrm{H}, \mathrm{m}), 5.39(1 \mathrm{H}, \mathrm{d}, J=6.1 \mathrm{~Hz}), 5.38(1 \mathrm{H}, 2 \times \mathrm{dd}, J=16$, $6 \mathrm{~Hz}), 5.26(1 \mathrm{H}, 2 \times \mathrm{dd}, J=10.3,1.6 \mathrm{~Hz}), 5.23(1 \mathrm{H}, \mathrm{d}, J=6.1$ $\mathrm{Hz}), 4.51(2 \mathrm{H}, \mathrm{m}), 1.00(3 \mathrm{H}, \mathrm{m}), 0.91(4 \mathrm{~s}, 18 \mathrm{H}) .{ }^{13} \mathrm{C}$ NMR $(125$ MHz) $\delta=166.3,165.4,158.6,135.4,133.4,133.3,132.1,129.9$, 129.2, 128.2, 120.9, 117.6, 114.8, 114.7, 76.7, 68.9, 61.1, 17.5, 17.4, 11.7. HRFABMS: $\mathrm{m} / \mathrm{z}$ calcd for $\mathrm{C}_{28} \mathrm{H}_{37} \mathrm{NO}_{4} \mathrm{Si}^{+} 479.2492$, found $479.2494(\Delta=0.5 \mathrm{ppm})$. Characterization data for compounds $\mathbf{7 b}-\mathbf{d}$ and $\mathbf{7 f}, \mathbf{g}$ are provided in the Supporting Information.

Representative Procedure for the Synthesis of Baccatin III Derivatives 11a-d. Synthesis of 4-Deacetyl-4-acryloyl-7-Otriethylsilylbaccatin III (11a).

(a) Synthesis of 1-Dimethylsilyl-4-deacetyl-4-acryloyl-4deacetyl-7- $O, 10-O, 13-O$-tris-triethylsilylbaccatin III (9a). Lithium hexamethyldisilazide (LiHMDS) (1 M, $1.3 \mathrm{~mL}, 1.3 \mathrm{mmol}, 1.2$ equiv) was added dropwise at $0{ }^{\circ} \mathrm{C}$ to a solution of 1-dimethylsilyl4-deacetyl-7-O,10-O,13-O-tris-triethylsilylbaccatin III ${ }^{46}(8)(1 \mathrm{~g}, 1.1$ $\mathrm{mmol})$ in THF $(6 \mathrm{~mL})$, and the resulting solution was stirred for $45 \mathrm{~min}$. Acryloyl chloride ( $0.123 \mathrm{~mL}, 1.54 \mathrm{mmol}, 1.3$ equiv) was added to the above solution at $0{ }^{\circ} \mathrm{C}$, and the reaction mixture stirred for $3 \mathrm{~h}$. Saturated $\mathrm{NH}_{4} \mathrm{Cl}$ solution $(10 \mathrm{~mL})$ was added, and the aqueous phase was subjected to the usual workup. The crude product as purified by chromatography over silica gel with $4 \%$ EtOAc in hexane to furnish 1-dimethylsilyl-4-deacetyl-4-acryloyl7-O,10-O,13-O-tris-triethylsilylbaccatin III (9a) as a white solid (550 mg, 52\%).

(b) Synthesis of 4-Deacetyl-4-acryloyl-10-deacetylbaccatin III. To a solution of 1-dimethylsilyl-4-deacetyl-4-acryloyl-7- $O, 10-O, 13$ $O$-tris-triethylsilylbaccatin III (9a) $(470 \mathrm{mg}, 0.49 \mathrm{mmol})$ in THF $(30 \mathrm{~mL})$ was added dropwise HF.Py $(70 \% \mathrm{HF}, 2.37 \mathrm{~mL})$ at $0{ }^{\circ} \mathrm{C}$, and the resulting solution was brought to room temperature over $24 \mathrm{~h}$, after which saturated $\mathrm{NaHCO}_{3}$ solution $(50 \mathrm{~mL})$ was added carefully to quench the reaction. The aqueous phase was subjected to the usual workup, and the crude product was purified by preparative thin layer chromatography on silica gel developed with $70 \%$ EtOAc in hexane to give 4-deacetyl-4-acryloyl-10-deacetylbaccatin III as a white solid (193 $\mathrm{mg}, 70 \%)$.

(c) Synthesis of 4-Deacetyl-4-acryloylbaccatin III (10a). Anhydrous $\mathrm{CeCl}_{3}(20 \mathrm{mg})$ was added to a solution of 4-deacetyl4-acryloyl-10-deacetyl-baccatin III ( $210 \mathrm{mg}, 0.377 \mathrm{mmol})$ in THF $(10 \mathrm{~mL})$ and the resulting solution was stirred for $5 \mathrm{~min}$. Acetic anhydride $(0.65 \mathrm{~mL}, 14$-fold excess) was added to the above solution and the reaction mixture was stirred for $4 \mathrm{~h}$. EtOAc $(100$ $\mathrm{mL}$ ) was added and the solution was washed with saturated $\mathrm{NaHCO}_{3}$, water, and brine, dried over $\mathrm{Na}_{2} \mathrm{SO}_{4}$, and concentrated. The crude product was subjected to preparative thin layer chromatography on silica gel with $60 \%$ EtOAc in hexane to give 4-deacetyl-4-acryloyl-baccatin III (10a) as a white solid (200 mg, $96 \%$ ).

(d) Synthesis of 4-Deacetyl-4-acryloyl-7-O-triethylsilylbaccatin III (11a). To a solution of 4-deacetyl-4-acryloylbaccatin III (10a) $(50 \mathrm{mg}, 0.083 \mathrm{mmol})$ in dichloromethane $(5 \mathrm{~mL})$ was added imidazole (56 mg, $0.836 \mathrm{mmol}, 10$ equiv) followed by triethylsilyl chloride $\left(0.50 \mathrm{mmol}, 6\right.$ equiv) at $0{ }^{\circ} \mathrm{C}$, and the resulting solution was stirred for $3 \mathrm{~h}$. Dilute $\mathrm{HCl}(0.05 \mathrm{M}, 5 \mathrm{~mL})$ solution was added to quench the reaction followed by EtOAc $(40 \mathrm{~mL})$. The organic phase was worked up in the usual way to give a crude product which was subjected to preparative thin layer chromatography over silica gel with $45 \%$ EtOAc in hexane to give 11a as a white solid (40 mg, 72\%). (11a): $\left.{ }^{1} \mathrm{H} \mathrm{NMR} \mathrm{(500} \mathrm{MHz,} \mathrm{CDCl}_{3}\right) \delta=8.11(2 \mathrm{H}$, $\mathrm{d}, J=7.1 \mathrm{~Hz}), 7.59(1 \mathrm{H}, \mathrm{t}, J=7.2 \mathrm{~Hz}), 7.46(2 \mathrm{H}, \mathrm{t}, J=7.2 \mathrm{~Hz})$, $6.52(1 \mathrm{H}, \mathrm{dd}, J=17.4,1.2 \mathrm{~Hz}, 1 \mathrm{H}), 6.47(1 \mathrm{H}, \mathrm{s}), 6.28(1 \mathrm{H}, \mathrm{dd}, J$ $=17.4,10.5 \mathrm{~Hz}), 6.01(1 \mathrm{H}, \mathrm{dd}, J=17.4,1.2 \mathrm{~Hz}), 5.64(1 \mathrm{H}, \mathrm{d}, J$ $=6.8 \mathrm{~Hz}), 4.94(1 \mathrm{H}, \mathrm{d}, J=7.7 \mathrm{~Hz}), 4.76(1 \mathrm{H}, \mathrm{m}), 4.53(1 \mathrm{H}, \mathrm{dd}$, $J=10,6.7 \mathrm{~Hz}), 4.33(1 \mathrm{H}, \mathrm{d}, J=8.4 \mathrm{~Hz}), 4.20(1 \mathrm{H}, \mathrm{d}, J=8.4$ $\mathrm{Hz}), 3.94(1 \mathrm{H}, \mathrm{d}, J=6.8 \mathrm{~Hz}), 2.55(1 \mathrm{H}, \mathrm{m}), 2.20(3 \mathrm{H}, \mathrm{s}), 2.22-$ $2.10(2 \mathrm{H}, \mathrm{m}), 2.18(3 \mathrm{H}, \mathrm{s}), 1.90(1 \mathrm{H}, \mathrm{m}), 1.70(3 \mathrm{H}, \mathrm{s}), 1.18(3 \mathrm{H}$, s), $1.02(3 \mathrm{H}, \mathrm{s}), 0.91(9 \mathrm{H}, \mathrm{t}, J=7.2 \mathrm{~Hz}), 0.60(6 \mathrm{H}, \mathrm{m}) .{ }^{13} \mathrm{C} \mathrm{NMR}$ $(125 \mathrm{MHz}) \delta=202.2,169.4,167.1,165.3,144.0,133.7,131.2$, 130.1, 129.8, 129.6, 128.6, 84.2, 81.3, 78.8, 76.6, 75.8, 74.8, 72.4, $68.1,58.8,47.2,42.8,38.9,37.3,26.9,21.0,20.1,14.9,10.0,6.84$, 5.36. HRFABMS $\mathrm{m} / z$ calcd for $\mathrm{C}_{38} \mathrm{H}_{53} \mathrm{O}_{11} \mathrm{Si}^{+} 713.3357$, found $713.3326(\Delta=4.4 \mathrm{ppm})$. Characterization data for compounds $\mathbf{1 1 b}-\mathbf{d}$ are provided in the Supporting Information.

Representative Procedures for the Coupling of Baccatin III Derivatives 11a-d with $\beta$-Lactam Derivatives 7a-d and 7f-g. A typical procedure is described for the synthesis of $3^{\prime}$-dephenyl- $3^{\prime}$ ( $m$-allyloxyphenyl)-4-deacetyl-4-acryloyl-7- $O$-triethylsilyl-2'-O-triisopropylsilylpaclitaxel (12a).

Synthesis of $3^{\prime}$-Dephenyl-3'-( $m$-allyloxyphenyl)-4-deacetyl-4acryloyl-7- $O$-triethylsilyl-2' $O$-triisopropylsilylpaclitaxel (12a). To a solution of baccatin III derivative 11a $(25 \mathrm{mg}, 0.035 \mathrm{mmol})$ and $\beta$-lactam derivative 7a (34 $\mathrm{mg}, 0.07 \mathrm{mmol}, 2$ equiv) in THF $(6.5 \mathrm{~mL})$ was added LiHMDS at $-40{ }^{\circ} \mathrm{C}$, and the resulting solution was stirred for $3 \mathrm{~h}$. Saturated aqueous $\mathrm{NH}_{4} \mathrm{Cl}(2 \mathrm{~mL})$ was added to quench the reaction, and usual workup gave crude product which was purified by preparative TLC using $20 \%$ EtOAc in hexane as solvent to give 12a (17 mg, 65\%). ${ }^{1} \mathrm{H}$ NMR (400 MHz) $\delta=8.10$ $(2 \mathrm{H}, \mathrm{dd}, J=7.2,1.6 \mathrm{~Hz}), 8.00(1 \mathrm{H}, \mathrm{m}), 7.73(2 \mathrm{H}, \mathrm{dd}, J=7.2,1.6$ $\mathrm{Hz}), 7.70-7.30(8 \mathrm{H}, \mathrm{m}), 7.04(1 \mathrm{H}, \mathrm{d}, J=8.8 \mathrm{~Hz}), 6.98(1 \mathrm{H}, \mathrm{d}, J$ $=8 \mathrm{~Hz}), 6.90(1 \mathrm{H}, \mathrm{bs}), 6.85(1 \mathrm{H}, \mathrm{d}, J=8 \mathrm{~Hz}), 6.63(1 \mathrm{H}, \mathrm{d}, J=$ $17.6 \mathrm{~Hz}), 6.52(1 \mathrm{H}, \mathrm{d}, J=18.4 \mathrm{~Hz}), 6.47(1 \mathrm{H}, \mathrm{s}), 6.44(1 \mathrm{H}, \mathrm{d}, J$ $=10.4 \mathrm{~Hz}), 6.16(1 \mathrm{H}, \mathrm{t}, J=7 \mathrm{~Hz}), 6.03(2 \mathrm{H}, \mathrm{m}), 5.93(1 \mathrm{H}, \mathrm{d}, J$ $=10.8 \mathrm{~Hz}), 5.72(1 \mathrm{H}, \mathrm{d}, J=8 \mathrm{~Hz}), 5.59(1 \mathrm{H}, \mathrm{d}, J=8.8 \mathrm{~Hz})$, $5.42(1 \mathrm{H}, \mathrm{dt}, J=17.2,1 \mathrm{~Hz}), 5.29(1 \mathrm{H}, \mathrm{dt}, J=10.4,1 \mathrm{~Hz}), 4.90$ $(1 \mathrm{H}, \mathrm{d}, J=9.6 \mathrm{~Hz}), 4.87(1 \mathrm{H}, \mathrm{s}), 4.65(2 \mathrm{H}, \mathrm{m}), 4.33(1 \mathrm{H}, \mathrm{d}, J=$ $8.8 \mathrm{~Hz}), 4.26(1 \mathrm{H}, \mathrm{d}, J=8.8 \mathrm{~Hz}), 3.90(1 \mathrm{H}, \mathrm{d}, J=7.2 \mathrm{~Hz}), 2.58$ $(1 \mathrm{H}, \mathrm{m}), 2.40(1 \mathrm{H}, \mathrm{m}), 2.17(3 \mathrm{H}, \mathrm{s}), 2.10(1 \mathrm{H}, \mathrm{m}), 2.08(3 \mathrm{H}, \mathrm{s})$, $1.92(1 \mathrm{H}, \mathrm{m}), 1.74(3 \mathrm{H}, \mathrm{s}), 1.62(3 \mathrm{H}, \mathrm{s}), 1.22(3 \mathrm{H}, \mathrm{s}), 1.16(3 \mathrm{H}, \mathrm{s})$, $0.95(30 \mathrm{H}, \mathrm{m}), 0.59(6 \mathrm{H}, \mathrm{m}) .{ }^{13} \mathrm{C}$ NMR $(100 \mathrm{MHz}) \delta=202.0$, $172.0,169.5,167.2,167.0,165.3,159.2,140.5,140.4,134.2,133.7$, 133.6, 133.3, 133.0, 131.9, 130.4, 130.1, 129.8, 129.6, 129.2, 128.9, $128.7,127.7,127.1,118.9,117.9,114.5,113.2,84.4,81.5,79.0$, $76.8,75.3,75.28,75.22,72.4,71.7,69.1,58.6,55.9,47.0,43.5$, 37.4, 26.7, 21.8, 21.1, 18.0, 14.4, 12.7, 10.4, 6.9, 5.5. HRFABMS $\mathrm{m} / \mathrm{z}$ calcd for $\mathrm{C}_{66} \mathrm{H}_{89} \mathrm{NO}_{15} \mathrm{Si}_{2} \mathrm{Na}^{+} 1214.5668$, found $1214.5668(\Delta$ $=0 \mathrm{ppm})$. Characterization data for compounds $\mathbf{1 2} \mathbf{b}-\mathbf{f}$ are provided in the Supporting Information.

Representative Procedure for the Deprotection of 12a-i. Synthesis of $3^{\prime}$-Dephenyl-3'-( $m$-allyloxyphenyl)-4-deacetyl-4acryloylpaclitaxel (13a). To a solution of $3^{\prime}$-dephenyl-3'-( $m$ allyloxyphenyl)-4-deacetyl-4-acryloyl-7- $O$-triethylsilyl-2'- $O$-triisopropylsilylpaclitaxel (12a, $15 \mathrm{mg}, 0.012 \mathrm{mmol})$ in THF $(5 \mathrm{~mL})$ was added hydrogen fluoride-pyridine complex $(70 \%, 0.2 \mathrm{~mL})$ at $0{ }^{\circ} \mathrm{C}$, and the resulting solution was brought to room temperature overnight. Saturated $\mathrm{NaHCO}_{3}$ solution $(5 \mathrm{~mL})$ was added carefully to quench the reaction. Usual workup followed by preparative TLC (silica gel, 50\% EtOAc in hexane) furnished 13a $(5.5 \mathrm{mg}, 55 \%)$. (13a): ${ }^{1} \mathrm{H} \mathrm{NMR}\left(400 \mathrm{MHz}, \mathrm{CDCl}_{3}\right) \delta=8.15(2 \mathrm{H}, \mathrm{d}, J=7.2 \mathrm{~Hz})$, $7.72(2 \mathrm{H}, \mathrm{d}, J=8 \mathrm{~Hz}), 7.61(1 \mathrm{H}, \mathrm{t}, J=7 \mathrm{~Hz}), 7.50(3 \mathrm{H}, \mathrm{m}), 7.40$ $(3 \mathrm{H}, \mathrm{m}), 7.10(2 \mathrm{H}, \mathrm{m}), 6.91(1 \mathrm{H}, \mathrm{d}, J=7.6 \mathrm{~Hz}) ,6.83(1 \mathrm{H}, \mathrm{d}, J=$ $9.2 \mathrm{~Hz}), 6.50(1 \mathrm{H}, \mathrm{dd}, J=17.6,1.2 \mathrm{~Hz}), 6.35(1 \mathrm{H}, \mathrm{d}, J=10.4$ $\mathrm{Hz}), 6.29(1 \mathrm{H}, \mathrm{s}), 6.1(1 \mathrm{H}, \mathrm{m}), 6.05(1 \mathrm{H}, \mathrm{m}), 5.68(3 \mathrm{H}, \mathrm{m}), 5.47$ $(1 \mathrm{H}, \mathrm{dd}, J=9.2,1.6 \mathrm{~Hz}), 5.30(1 \mathrm{H}, \mathrm{dq}, J=17.2,1.6 \mathrm{~Hz}), 5.30$ $(1 \mathrm{H}, \mathrm{dq}, J=10.5,1.2 \mathrm{~Hz}), 4.92(1 \mathrm{H}, \mathrm{dd}, J=9.4,1.6 \mathrm{~Hz}), 4.74$ $(1 \mathrm{H}, \mathrm{d}, J=2 \mathrm{~Hz}), 4.56(2 \mathrm{H}, \mathrm{m}), 4.48(1 \mathrm{H}, \mathrm{dd}, J=10.4,6.8 \mathrm{~Hz})$, 
$4.34(1 \mathrm{H}, \mathrm{d}, J=8.4 \mathrm{~Hz}), 4.25(1 \mathrm{H}, \mathrm{d}, J=8.4 \mathrm{~Hz}), 3.86(1 \mathrm{H}, \mathrm{d}$, $J=6.8 \mathrm{~Hz}), 2.58(1 \mathrm{H}, \mathrm{m}), 2.42(1 \mathrm{H}, \mathrm{m}), 2.30(1 \mathrm{H}, \mathrm{m}), 2.24(3 \mathrm{H}$, s), $1.90(1 \mathrm{H}, \mathrm{m}), 1.83(3 \mathrm{H}, \mathrm{s}), 1.70(3 \mathrm{H}, \mathrm{s}), 1.62(1 \mathrm{H}, \mathrm{m}), 1.22$ $(3 \mathrm{H}, \mathrm{s}), 1.14(3 \mathrm{H}, \mathrm{s}) .{ }^{13} \mathrm{C} \mathrm{NMR}(100 \mathrm{MHz}) \delta=203.8,173.3,171.5$, 167.2, 167.1, 165.4, 159.3, 142.3, 140.1, 133.9, 133.4, 133.2, 132.4, $132.1,130.4,130.2,129.5,129.3,128.94,128.91,127.2,119.6$, 118.2, 114.5, 114.0, 84.6, 81.6, 79.1, 76.7, 75.8, 75.2, 72.7, 72.3, 72.2, 69.1, 58.8, 54.5, 45.9, 43.3, 35.9, 35.7, 32.1, 29.9, 27.0, 24.9, 22.9, 22.0, 21.0, 15.1, 9.8. HRFABMS m/z calcd for $\mathrm{C}_{51} \mathrm{H}_{56} \mathrm{NO}_{15}{ }^{+}$ 922.3650, found $922.36676(\Delta=2.9 \mathrm{ppm})$. Similar procedures were employed to prepare compounds $\mathbf{1 3 b}-\mathbf{j}$; characterization data for these compounds are provided in the Supporting Information.

Representative Procedure for Ring-Closing Metathesis of $12 \mathrm{a}-\mathrm{i}$. Synthesis of 7-O-Triethylsilyl-2'-O-triisopropylsilyl Bridged Paclitaxel 14a. Grubbs second generation catalyst $(2 \mathrm{mg})$ in $\mathrm{CH}_{2}-$ $\mathrm{Cl}_{2}(2.5 \mathrm{~mL})$ was added over $3 \mathrm{~h}$ to a solution of $\mathbf{1 2 a}(16 \mathrm{mg}$, $0.013 \mathrm{mmol})$ in $\mathrm{CH}_{2} \mathrm{Cl}_{2}(4 \mathrm{~mL})$, and the resulting solution was stirred for $1 \mathrm{~h}$. The reaction mixture was concentrated, and the crude mass was applied to preparative thin layer chromatography using $25 \%$ EtOAc in hexane as solvent to furnish 14a (10 mg, 65\%). 14a: ${ }^{1} \mathrm{H}$ NMR $(500 \mathrm{MHz}) \delta=8.10(2 \mathrm{H}, \mathrm{d}, J=7.1 \mathrm{~Hz}), 7.82(2 \mathrm{H}$, $\mathrm{d}, J=7.1 \mathrm{~Hz}), 7.65(1 \mathrm{H}, \mathrm{t}, J=7.3 \mathrm{~Hz}), 7.53(2 \mathrm{H}, \mathrm{m}), 7.45(3 \mathrm{H}$, m), $7.35(1 \mathrm{H}, \mathrm{m}), 7.21(2 \mathrm{H}, \mathrm{m}), 6.94(2 \mathrm{H}, \mathrm{m}), 6.46(1 \mathrm{H}, \mathrm{s}), 6.14$ $(1 \mathrm{H}, \mathrm{m}), 6.12(1 \mathrm{H}, \mathrm{d}, J=16 \mathrm{~Hz}), 5.73(1 \mathrm{H}, \mathrm{d}, J=7.3 \mathrm{~Hz}), 5.5$ $(1 \mathrm{H}, \mathrm{d}, J=6.6 \mathrm{~Hz}), 4.93(2 \mathrm{H}, \mathrm{m}), 4.85(1 \mathrm{H}, \mathrm{d}, J=8 \mathrm{~Hz}), 4.56$ $(1 \mathrm{H}, \mathrm{d}, J=2 \mathrm{~Hz}), 4.48(1 \mathrm{H}, \mathrm{dd}, J=10.5,6.6 \mathrm{~Hz}), 4.28(2 \mathrm{H}, \mathrm{s})$, $3.81(1 \mathrm{H}, \mathrm{d}, J=7.1 \mathrm{~Hz}), 2.50(1 \mathrm{H}, \mathrm{m}), 2.29(1 \mathrm{H}, \mathrm{m}), 2.18(3 \mathrm{H}, \mathrm{s})$, $2.16(1 \mathrm{H}, \mathrm{m}), 2.08(3 \mathrm{H}, \mathrm{s}), 1.99(3 \mathrm{H}, \mathrm{m}), 1.91(1 \mathrm{H}, \mathrm{m}), 1.74(3 \mathrm{H}$, s), $1.24(3 \mathrm{H}, \mathrm{s}), 1.17(3 \mathrm{H}, \mathrm{s}), 1.10(21 \mathrm{H}, \mathrm{m}), 0.9(9 \mathrm{H}, \mathrm{t}, J=7.8$ $\mathrm{Hz}), 0.57(6 \mathrm{H}, \mathrm{m}) .{ }^{13} \mathrm{C} \mathrm{NMR}(125 \mathrm{MHz}) \delta=201.8,171.5,169.5$, 167.3, 167.1, 164.1, 159.7, 147.0, 142.6, 140.5, 134.1, 134.0, 133.6, 132.0, 130.1, 130.0, 129.7, 128.9, 127.2, 123.8, 118.9, 118.2, 113.7, 84.4, 81.9, 79.1, 77.0, 75.2, 75.1, 72.7, 70.8, 70.0, 58.7, 57.6, 47.6, 43.4, 37.4, 35.9, 26.8, 21.6, 21.1, 18.1, 17.9, 14.5, 12.9, 10.3, 6.9, 5.5. HRFABMS $m / z$ calcd for $\mathrm{C}_{64} \mathrm{H}_{85} \mathrm{NO}_{15} \mathrm{Si}_{2} \mathrm{Na}^{+} 1186.5355$, found $1185.5330(\Delta=2.2 \mathrm{ppm})$. Similar procedures were employed to prepare compounds $\mathbf{1 4 b}-\mathbf{i}$; characterization data for these compounds are provided in the Supporting Information.

Representative Procedure for the Deprotection of Macrocyclic Paclitaxels 14a-j. Synthesis of Bridged Paclitaxel 15a. To a solution of 14a (9 mg, $0.0077 \mathrm{mmol})$ in THF (3.5 mL) was added hydrogen fluoride-pyridine complex $(70 \%, 0.15 \mathrm{~mL})$ at $0{ }^{\circ} \mathrm{C}$, and the resulting solution was brought to room temperature overnight. Saturated $\mathrm{NaHCO}_{3}$ solution $(5 \mathrm{~mL})$ was added carefully to quench the reaction and after the usual workup resulted the crude product was purified by preparative TLC (silica gel, 60\% EtOAc in hexane) to furnish 15a $(6.3 \mathrm{mg}, 91 \%)$. 15a: ${ }^{1} \mathrm{H}$ NMR $(400 \mathrm{MHz}) \delta=7.98$ $(2 \mathrm{H}, \mathrm{d}, J=7.6 \mathrm{~Hz}), 7.80(2 \mathrm{H}, \mathrm{d}, J=7.6 \mathrm{~Hz}), 7.69(1 \mathrm{H}, \mathrm{t}, J=7.6$ $\mathrm{Hz}), 7.61(1 \mathrm{H}, \mathrm{t}, J=6.8 \mathrm{~Hz}), 7.53(1 \mathrm{H}, \mathrm{m}), 7.44(2 \mathrm{H}, \mathrm{m}), 7.22$ $(1 \mathrm{H}, \mathrm{dd}, J=7.6 \mathrm{~Hz}), 7.10(1 \mathrm{H}, \mathrm{m}), 7.05(1 \mathrm{H}, \mathrm{bs}), 6.98(1 \mathrm{H}, \mathrm{m})$, $6.80(1 \mathrm{H}, \mathrm{bs}), 6.26(\mathrm{~s}, 1 \mathrm{H}), 6.13(1 \mathrm{H}, \mathrm{d}, J=16 \mathrm{~Hz}) 6.11(1 \mathrm{H}, \mathrm{d}$, $J=9.2 \mathrm{~Hz}), 5.60(1 \mathrm{H}, \mathrm{d}, J=6.8 \mathrm{~Hz}), 5.31(1 \mathrm{H}, \mathrm{dd}, J=9.3,6.4$ $\mathrm{Hz}), 5.04(1 \mathrm{H}, \mathrm{dd}, J=14.4,9.6 \mathrm{~Hz}), 4.88(2 \mathrm{H}, \mathrm{m}), 4.48(1 \mathrm{H}, \mathrm{d}, J$ $=9.6 \mathrm{~Hz}), 4.37(1 \mathrm{H}, \mathrm{m}), 4.21(2 \mathrm{H}, \mathrm{s}), 3.68(1 \mathrm{H}, \mathrm{d}, J=6.8 \mathrm{~Hz})$, $2.58(2 \mathrm{H}, \mathrm{m}), 2.22(3 \mathrm{H}, \mathrm{s}), 1.90(1 \mathrm{H}, \mathrm{m}), 1.84(3 \mathrm{H}, \mathrm{s}), 1.78(1 \mathrm{H}$, $\mathrm{m}), 1.68(3 \mathrm{H}, \mathrm{s}), 1.53(1 \mathrm{H}, \mathrm{m}), 1.25-1.22(1 \mathrm{H}, \mathrm{m}), 1.21(3 \mathrm{H}, \mathrm{s})$, $1.0(3 \mathrm{H}, \mathrm{s}) .{ }^{13} \mathrm{C}$ NMR $(100 \mathrm{MHz}) \delta=203.7,173.0,171.5,169.3$, 167.0, 163.6, 155.7, 143.3, 142.9, 138.4, 134.1, 133.6, 132.6, 132.4, $131.2,130.1,129.6,128.9,127.3,126.8,122.5,119.3,111.2,84.3$, 81.5, 79.4, 77.4, 76.7, 76.4, 75.7, 75.1, 72.5, 70.5, 66.1, 58.8, 58.6, $45.9,43.2,35.7,35.0,27.0,22.3,21.0,14.8,9.7$. HRFABMS $\mathrm{m} / \mathrm{z}$ calcd for $\mathrm{C}_{49} \mathrm{H}_{52} \mathrm{NO}_{15} 894.3337$, found 894.3294 ( $\left.\Delta=4.8 \mathrm{ppm}\right)$. Similar procedures were employed to prepare compounds $\mathbf{1 5} \mathbf{b}-\mathbf{j}$; characterization data for these compounds are provided in the Supporting Information.

Representative Procedure for the Hydrogenation of Macrocyclic Paclitaxels 15a-j. Synthesis of Dihydro Bridged Paclitaxel 16a. To a solution of 15a $(6 \mathrm{mg}, 0.0067 \mathrm{mmol})$ in methanol $(5$ $\mathrm{mL})$ was added $10 \% \mathrm{Pd}-\mathrm{C}(10 \mathrm{mg})$ and hydrogenated at $35 \mathrm{psi}$ for $6 \mathrm{~h}$. The reaction mixture was filtered a through short plug of silica gel, eluting with $20 \%$ methanol in EtOAc. The filtrate was concentrated to crude mass, which was applied to silica gel preparative plate using $65 \%$ EtOAc in hexane as solvent provided the dihydro bridged paclitaxel 16a (5 mg, 83\% yield). 16a: ${ }^{1} \mathrm{H}$ NMR $(400 \mathrm{MHz}) \delta=8.06(2 \mathrm{H}, \mathrm{d}, J=7.2 \mathrm{~Hz}), 7.82(2 \mathrm{H}, \mathrm{d}, J=7.2$ $\mathrm{Hz}), 7.10-7.03(4 \mathrm{H}, \mathrm{m}), 7.55-7.45(4 \mathrm{H}, \mathrm{m}), 7.19(1 \mathrm{H}, \mathrm{t}, J=7.6$ $\mathrm{Hz}), 7.08(1 \mathrm{H}, \mathrm{bs}), 6.96-6.88(2 \mathrm{H}, \mathrm{m}), 6.19(1 \mathrm{H}, \mathrm{s}), 6.14(1 \mathrm{H}, \mathrm{t}$, $J=8.8 \mathrm{~Hz}) 5.57(1 \mathrm{H}, \mathrm{d}, J=7.2 \mathrm{~Hz}), 5.24(1 \mathrm{H}, \mathrm{dd}, J=10.6,6.8$ $\mathrm{Hz}), 4.89(1 \mathrm{H}, \mathrm{d}, J=8.4 \mathrm{~Hz}), 4.62(1 \mathrm{H}, \mathrm{m}), 4.42(2 \mathrm{H}, \mathrm{m}), 4.32$ $(1 \mathrm{H}, \mathrm{m}), 4.22(1 \mathrm{H}, \mathrm{d}, J=7.2 \mathrm{~Hz}), 3.52(1 \mathrm{H}, \mathrm{d}, J=6.8 \mathrm{~Hz}), 2.70$ $(1 \mathrm{H}, \mathrm{m}), 2.50(5 \mathrm{H}, \mathrm{m}), 2.23(1 \mathrm{H}, \mathrm{m}), 2.22(3 \mathrm{H}, \mathrm{s}), 2.04(3 \mathrm{H}, \mathrm{s})$, $1.88(1 \mathrm{H}, \mathrm{m}), 1.65(3 \mathrm{H}, \mathrm{s}), 1.60(4 \mathrm{H}, \mathrm{m}), 1.42(3 \mathrm{H}, \mathrm{s}), 1.10(3 \mathrm{H}$, s). ${ }^{13} \mathrm{C} \mathrm{NMR}(100 \mathrm{MHz}) \delta=203.6,172.9,171.5,170.7,167.0$, 159.7, 142.7, 137.6, 134.2, 133.6, 133.5, 132.8, 132.4, 131.3, 130.4, $129.4,129.07,129.0,127.4,127.3,122.1,119.0,109.6,84.4,80.9$, 79.6, 76.3, 75.6, 74.9, 72.4, 70.5, 64.9, 64.5, 60.6, 59.7, 58.4, 45.7, 43.2, 38.3, 35.5, 35.1, 32.1, 31.4, 30.8, 29.92, 29.89, 29.5, 27.8, 27.1, 22.5, 21.0, 19.3, 14.7, 14.3, 13.9, 9.7. HRFABMS $\mathrm{m} / z$ calcd for $\mathrm{C}_{49} \mathrm{H}_{54} \mathrm{NO}_{15} \mathrm{Na}^{+}$918.3313, found 918.3337 ( $\Delta=2.6 \mathrm{ppm}$ ).

NAMFIS Analysis: 2D NMR-ROESY Spectra for 15f and 18f. The $1 \mathrm{D}{ }^{1} \mathrm{H}$ assignments of $\mathbf{1 5 f}$ and $\mathbf{1 8 f}$ were accomplished by interpretation of the corresponding COSY, HMBC, and HSQC spectra. The 2D NMR ROESY analysis for both compounds was performed on an INOVA $400 \mathrm{MHz}$ NMR spectrometer with 70, $100,125,150,180 \mathrm{~ms}$ mixing times to check linearity of the crossrelaxation buildup rates. Interproton distances were calculated from the integrated cross-peak volumes using the initial rate approximation and an internal calibration distance between H-6a and H-6b of $1.77 \AA$. This provided 19 and 15 ROE-based interproton distances for $\mathbf{1 5 f}$ and 18f, respectively.

Solution Conformation Deconvolution for $15 f$ and $18 f$. A 10000 -step conformational search was performed on both molecules with the MMFF94s force field and the $\mathrm{GBSA} / \mathrm{H}_{2} \mathrm{O}$ solvation model in MacroModel v7.2. An energy cutoff of $12 \mathrm{kcal} / \mathrm{mol}$ resulted in a pool of 93 and 374 unique conformations for $\mathbf{1 5 f}$ and 18f, respectively, with the global minimum found 62 and 29 times, respectively. The NAMFIS methodology integrated 19 ROEdetermined distances measured in $\mathrm{CDCl}_{3}$ and the 93 conformers of $\mathbf{1 5 f}$ to deconvolute the NMR data into four conformations. One of these, however, places the $\mathrm{C}-4$ acetate $\mathrm{C}=\mathrm{O}$ beneath the oxetane ring. Inspection of literature X-ray structures of PTX and analogues shows that the carbonyl group consistently resides beneath the sixmembered C-ring. Quantum chemical calculations (B3LYP/6-31G*, not shown) also demonstrate that oxetane orientation is ca. $4 \mathrm{kcal} /$ mol higher in energy. Thus the 93 conformers were depleted of the latter conformation, and NAMFIS was rerun to give five conformations with populations of $40,27,17,9$, and $7 \%$. (SSD $=$ 59). The dominant conformer is the T-form (40\%), while the second and fourth most populated structures (27 and 9\%, respectively) are slightly collapsed variants of the T-conformation in which the C3'benzamido phenyl to C2-phenyl centroid distance is $3 \AA$ A shorter. The third and fifth conformers (17 and 7\%, respectively) are somewhat extended structures that can be classified as neither $\mathrm{T}$ nor polar forms. For 18f, the 374 conformations likewise included a subset of carbonyl/oxetane structures, one of which appeared in the initial NAMFIS run employing 15 ROE-determined distances. These high-energy structures were removed from the dataset. A second NAMFIS run yielded three conformations with populations of 53,33 , and $14 \%$ (SSD =96). One is the T-conformation $(53 \%)$, the second, a slightly collapsed T-structure $(33 \%)$, and the third, the polar conformer (14\%).

Glide Docking. The top populated NAMFIS-derived conformation of $\mathbf{1 5 f}$ was docked into the $1 \mathrm{JFF}$ tubulin pocket using Glide ${ }^{58}$ in Maestro. An initial rigid dock of the ligand did not allow it to be situated in the pocket, so a follow-up flexible dock using the extra precision (XP) option was performed. It resulted in three very similar poses, all in the T-shape form, with the top pose differing from the NAMFIS conformation with an rms deviation of only 0.6 $\AA$ when all heavy atoms $(\mathrm{C}, \mathrm{N}, \mathrm{O})$ were superposed.

Biological Data. $\mathrm{IC}_{50}$ values were determined using the published method $^{59}$ for A2780 cells, the MTT assay ${ }^{60}$ for PC 3 cells, and the sulforhodamine-B method for the paclitaxel-resistant cell lines. ${ }^{55}$ 
$\mathrm{ED}_{50}$ values for induction of tubulin assembly were determined using either light scattering at $350 \mathrm{~nm}$ in a Hewlett-Packard 8453 absorption spectrometer or fluorescence in a 96-well plate format. ${ }^{61}$

Acknowledgment. This work was supported by the National Cancer Institute, National Institutes of Health (Grant CA-69571), and we are grateful for this support. We are likewise grateful to William Bebout and Rebecca Guza in the Department of Chemistry, Virginia Polytechnic Institute and State University, for mass spectra and preliminary cytotoxicity determinations, respectively. We are pleased to acknowledge the support and encouragement of Prof. Dennis Liotta (Department of Chemistry, Emory University).

Supporting Information Available: Characterization data for new compounds $7 \mathbf{b}-\mathbf{d}, \mathbf{f}, \mathbf{g}, \mathbf{1 1 b}-\mathbf{d}, \mathbf{1 2 b}-\mathbf{k}, \mathbf{1 3 b}-\mathbf{j}, \mathbf{1 4 c}, \mathbf{d}, \mathbf{f}-\mathbf{k}$, 15c,d,f-k, 16c,d,f-j, 25, 26, 28, 31a,b, and 32a,b; ${ }^{1} \mathrm{H}$ NMR spectra of compounds $\mathbf{1 5 c}, \mathbf{d}, \mathbf{f}, \mathbf{1 5 f}$ (expanded), $\mathbf{1 5 f}$ (COSY), 16c,f, 25, 31a,b, and 32a,b. This material is available free of charge via the Internet at http://pubs.acs.org.

\section{References}

(1) (a) Rowinsky, E. K.; The Development and Clinical Utility of the Taxane Class of Antimicrotuble Chemotherapy Agents. Annu. Rev. Med. 1997, 48, 353-374. (b) Crown, J.; O'Leary, M. The Taxanes: an Update. The Lancet 2000, 355, 1176-1178.

(2) Halkin, A.; Stone, G. W. Polymer-based Paclitaxel-eluting Stents in Percutaneous Coronary Intervention: A Review of the TAXUS Trials. J. Intervent. Cardiol. 2004, 17, 271-282.

(3) (a) Bollag, D. M.; McQueney, P. A.; Zhu, J.; Hensens, O.; Koupal, L.; Liesch, J.; Goetz, M.; Lazarides, E.; Woods, C. M. Epothilones, a New Class of Microtubule-stabilizing Agents with a Taxol-like Mechanism of Action. Cancer Res. 1995, 55, 2325-2333. (b) Kowalski, R. J.; Giannakakou, P.; Hamel, E. Activities of the Microtubule-stabilizing Agents Epothilones A and B with Purified Tubulin and in Cells Resistant to Paclitaxel (Taxol). J. Biol. Chem 1997, 272, 2534-2541.

(4) ter Haar, E.; Kowalski, R. J.; Hamel, E.; Lin, C. M.; Longley, R. E.; Gunasekera, S. P.; Rosenkranz, H. S.; Day, B. W. Discodermolide, a Cytotoxic Marine Agent that Stabilizes Microtubules More Potently than Taxol. Biochemistry 1996, 35, 243-250.

(5) Gapud, E. J.; Bai, R.; Ghosh, A. K.; Hamel, E., Laulimalide and Paclitaxel: A Comparison of their Effects on Tubulin Assembly and their Synergistic Action when Present Simultaneously. Mol. Pharmacol. 2004, 66, 113-121.

(6) Lindel, T.; Jensen, P. R.; Fenical, W.; Long, B. H.; Casazza, A. M.; Carboni, J.; Fairchild, C. R. Eleutherobin, a New Cytotoxin that Mimics Paclitaxel (Taxol) by Stabilizing Microtubules. J. Am. Chem. Soc. 1997, 119, 8744-8745.

(7) Schiff, P. B.; Fant, J.; Horwitz, S. B. Promotion of Microtubule Assembly in vitro by Taxol. Nature 1979, 277, 665-667.

(8) Horwitz, S. B. Mechanism of Action of Taxol. Trends Pharmacol. Sci. 1992, 13, 134-136.

(9) Jordan, M. A.; Toso, R. J.; Thrower, D.; Wilson, L. Mechanism of Mitotic Block and Inhibition of Cell Proliferation by Taxol at Low Concentrations. Proc. Natl. Acad. Sci. 1993, 90, 9552-9556.

(10) Blagosklonny, M. V.; Fojo, T. Molecular Effects of Paclitaxel: Myths and Reality (a Critical Review). Int. J. Cancer 1999, 83, 151-156.

(11) (a) Sunters, A.; Madureira, P. A.; Pomeranz, K. M.; Aubert, M.; Brosens, J. J.; Cook, S. J.; Burgering, B. M.; Coombes, R. C.; Lam, E. W. Paclitaxel-induced Nuclear Translocation of FOXO3a in Breast Cancer Cells is Mediated by c-Jun NH2-terminal Kinase and Akt. Cancer Res. 2006, 66, 212-220. (b) Faried, L. S.; Faried, A.; Kanuma, T.; Nakazato, T.; Tamura, T.; Kuwano, H.; Minegishi, T. Inhibition of the Mammalian Target of Rapamycin (mTOR) by Rapamycin Increases Chemosensitivity of CaSki Cells to Paclitaxel. Eur. J. Cancer 2006, 42, 934-947.

(12) Nogales, E.; Wolf, S. G.; Downing, K. H. Structure of the $\alpha \beta$ Tubulin Dimer by Electron Crystallography. Nature 1998, 391, 199-203.

(13) Lowe, J.; Li, H.; Downing, K. H.; Nogales, E. Refined Structure of $\alpha \beta$-Tubulin at $3.5 \AA$ Resolution. J. Mol. Biol. 2001, 313, 10451057.

(14) Dubois, J.; Guenard, D.; Gueritte-Voeglein, F.; Guedira, N.; Potier, P.; Gillet, B.; Betoeil, J-C. Conformation of Taxotere and Analogues Determined by NMR Spectroscopy and Molecular Modeling Studies. Tetrahedron 1993, 49, 6533-44.
(15) Williams, H. J.; Scott, A. I.; Dieden, R. A.; Swindell, C. S.; Chirlian, L. E.; Francl, M. M.; Heerding, J. M.; Krauss, N. E. NMR and Molecular Modeling Study of Active and Inactive Taxol Analogues in Aqueous and Non Aqueous Solution. Can. J. Chem. 1994, 72, 252-60.

(16) Cachau, R. E.; Gussio, R.; Beutler, J. A.; Chmurny, G. N.; Hilton, B. D.; Muschik, G. M.; Erickson, J. W. Solution Structure of Taxol Determined Using a Novel Feedback-scaling Procedure for NOErestrained Molecular Dynamics. Supercomput. Appl. High Perform. Comput. 1994, 8, 24-34.

(17) Vander Velde, D. G.; Georg, G. I.; Grunewald, G. L.; Gunn, C. W.; Mitscher, L. A. "Hydrophobic Collapse" of Taxol and Taxotere Solution Conformations in Mixtures of Water and Organic Solvent. J. Am. Chem. Soc. 1993, 115, 11650-1.

(18) Paloma, L. G.; Guy, R. K.; Wrasidlo, W.; Nicolaou, K. C. Conformation of a Water-soluble Derivative of Taxol in Water by 2D-NMR Spectroscopy. Chem. Biol. 1994, 1, 107-12.

(19) Ojima, I.; Chakravarty, S.; Inoue, T.; Lin, S.; He, L.; Horwitz, S. B.; Kuduk, S. C.; Danishefsky, S. J. A Common Pharmacophore for Cytotoxic Natural Products that Stabilize Microtubules. Proc. Natl. Acad. Sci. U.S.A. 1999, 96, 4256-61.

(20) Ojima, I.; Kuduk, S. D.; Chakravarty, S.; Ourevitch, M.; Begue, J-P. A Novel Approach to the Study of Solution Structures and Dynamic Behavior of Paclitaxel and Docetaxel Using Fluorine-Containing Analogues as Probes. J. Am. Chem. Soc. 1997, 119, 5519-27.

(21) Ojima, I.; Inoue, T.; Chakravarty, S. Enantiopure Fluorine-containing Taxoids: Potent Anticancer Agents and Versatile Probes for Biomedical Problems. J. Fluorine Chem. 1999, 97, 3-10.

(22) Snyder, J. P.; Nevins, N.; Cicero, D. O.; Jansen, J. The Conformations of Taxol in Chloroform. J. Am. Chem. Soc. 2000, 122, 724-5.

(23) Snyder, J. P.; Nevins, N.; Jimenez-Barbero, Cicero, D.; Jansen, J. M. Unpublished.

(24) Li, Y.; Poliks, B.; Cegelski, L.; Poliks, M.; Gryczynski, Z.; Piszczek, G.; Jagtap, P. G.; Studelska, D. R.; Kingston, D. G. I.; Schaefer, J. Bane, S. Conformation of Microtubule-Bound Paclitaxel Determined by Fluorescence Spectroscopy and REDOR NMR. Biochemistry 2000, 39, 281-291.

(25) Barboni, L.; Lambertucci, C.; Appendino, G.; Vander Velde, D. G.; Himes, R. H.; Bombardelli, E.; Wang, M.; Snyder, J. P. Synthesis and NMR-Driven Conformational Analysis of Taxol Analogoues Conformationally Constrained on the $\mathrm{C} 13$ Side Chain. J. Med. Chem. 2001, 44, 1576-1587.

(26) Boge, T. C.; Wu, Z-J.; Himes, R. H.; Vander Velde, D. G.; Georg, G. I. Conformationally Restricted Paclitaxel Analogues: Macrocyclic Mimics of the "Hydrophobic Collapse" Conformation. Bioorg. Med. Chem. Lett. 1999, 9, 3047-52.

(27) Ojima, I.; Lin, S.; Inoue, T.; Miller, M. L.; Borella, C. P.; Geng, X.; Walsh, J. J. Macrocycle Formation by Ring-closing Metathesis Application to the Syntheses of Novel Macrocyclic Taxoids. J. Am. Chem. Soc. 2000, 122, 5343-53.

(28) Ojima, I.; Geng, X.; Lin, S.; Pera, P.; Bernacki, R. J. Design, Synthesis and Biological Activity of Novel C2-C3.' N-Linked Macrocyclic Taxoids. Bioorg. Med. Chem. Lett. 2002, 12, 349-52.

(29) Geng, X.; Miller, M. L.; Lin, S.; Ojima, I. Synthesis of Novel C2C3.'N-Linked Macrocyclic Taxoids by Means of Highly Regioselective Heck Macrocyclization. Org. Lett. 2003, 5, 3733-6.

(30) Querolle, O.; Dubois, J.; Thoret, S.; Dupont, C.; Guéritte, F.; Guénard, D. Synthesis of Novel 2-O,3'-N-Linked Macrocyclic Taxoids with Variable Ring Size. Eur. J. Org. Chem. 2003, 542-50.

(31) Querolle, O.; Dubois, J.; Thoret, S.; Roussi, F.; Montiel-Smith, S.; Guéritte, F.; Guénard, D. Synthesis of Novel Macrocyclic Docetaxel Analogues. Influence of Their Macrocyclic Ring Size on Tubulin Activity. J. Med. Chem. 2003, 46, 3623-30.

(32) (a) Querolle, O.; Dubois, J.; Thoret, S.; Roussi, F.; Guéritte, F. Guénard, D. Synthesis of C2-C3.' N-Linked Macrocyclic Taxoids. Novel Docetaxel Analogues with High Tubulin Activity. J. Med. Chem. 2004, 47, 5937-5944. (b) Geney, R.; Sun, L.; Pera, P.; Bernacki, R. J.; Xia, S.; Horwitz, S. B.; Simmerling, C. L.; Ojima, I. Use of the Tubulin Bound Paclitaxel Conformation for StructureBased Rational Drug Design. Chem. Biol. 2005, 12, 339-348.

(33) Kingston, D. G. I.; Bane, S.; Snyder, J. P. The Taxol Pharmacophore and the T-Taxol Bridging Principle. Cell Cycle 2005, 4, 279-289.

(34) Guéritte-Voegelein, F.; Guénard, D.; Mangatal, L.; Potier, P.; Guilhem, J.; Césario, M.; Pascard, C. Structure of a Synthetic Taxol Precursor: N-tert-Butoxycarbonyl-10-deacetyl-N-debenzoyltaxol. Acta Crystallogr. C 1990, 46, 781-784.

(35) Cicero, D. O.; Barbato, G.; Bazzo, R.; NMR Analysis of Molecular Flexibility in Solution: A New Method for the Study of Complex Distributions of Rapidly Exchanging Conformations. Application to a 13-Residue Peptide with an 8-Residue Loop. J. Am. Chem. Soc. 1995, 117, 1027-33. 
(36) Snyder, J. P.; Nettles, J. H.; Cornett, B.; Downing, K. H.; Nogales, E. The Binding Conformation of Taxol in $\beta$-Tubulin: A Model Based on the Electron Crystallographic Density. Proc. Natl. Acad. Sci. U.S.A. 2001, 98, 5312-5316.

(37) Ganesh, T.; Guza, R. C.; Bane, S.; Ravindra, R.; Shanker, N.; Lakdawala, A. S; Snyder, J. P.; Kingston, D. G. I. The Bioactive Taxol Conformation on $\beta$-tubulin: Experimental Evidence from Highly Active Constrained Analogs. Proc. Natl. Acad. Sci. U.S.A. 2004, 101, 10006-10011.

(38) Metaferia, B. B; Hoch, J.; Glass, T. E; Bane, S. L.; Chatterjee, S K.; Snyder, J. P.; Lakdawala, A.; Cornett, B.; Kingston, D. G. I. Synthesis and Biological Evaluation of Novel Macrocyclic Paclitaxel Analogues. Org. Lett. 2001, 3, 2461-2464.

(39) Paik, Y.; Yang, C.; Metaferia, B.; Tang, S.; Bane, S.; Ravindra, R.; Shanker, N.;Alcaraz, A. A. Snyder, J. P.;Schaefer, J.; O’Connor, R. D.; Cegelski, L.; Kingston, D. G. I. REDOR NMR Distance Measurements for the Tubulin-Bound Paclitaxel Conformation. J. Am. Chem. Soc. 2007, 129, 361-370.

(40) Tang, S.; Yang, C.; Brodie, P.; Bane, S.; Ravindra, R.; Sharma, S.; Jiang, Y.; Snyder, J. P.; Kingston, D. G. I. Bridging Converts a Noncytotoxic nor-Paclitaxel Derivative to a Cytotoxic Analogue by Constraining it to the T-Taxol Conformation. Org. Lett. 2006, 8, 3983-3986.

(41) For the leading references, see: (a) Trnka, T. M.; Grubbs, R.H. The Development of $\mathrm{L}_{2} \mathrm{X}_{2} \mathrm{Ru}=\mathrm{CHR}$ Olefin Metathesis Catalysts: An Organometallic Success Story. Acc. Chem. Res. 2001, 34, 18-29, and references cited therein. (b) Fürstner, A. Olefin Metathesis and Beyond. Angew. Chem., Int. Ed. 2000, 39, 3012-3043. (c) Grubbs, R. H.; Chang, S. Recent Advances in Olefin Metathesis and its Applications in Organic Synthesis. Tetrahedron 1998, 54, 44134450. and references cited therein.

(42) For the synthesis of various substituted racemic $\beta$-lactams, see: Carr, J. A.; Al-Azemi, T. F.; Long, T. E.; Shim, J-Y.; Coates, C. M.; Turos, E.; Bisht, K. S. Lipase Catalyzed Resolution of 4-Aryl Substituted $\beta$-Lactams: Effect of Substitution on the 4-Aryl Ring. Tetrahedron 2003, 59, 9147-9160, and references cited therein.

(43) Brieva, R.; Crich, J. Z.; Sih, C. J. Chemoenzymatic Synthesis of the C-13 Side Chain of Taxol: Optically Active 3-Hydroxy-4-phenyl $\beta$-lactam Derivatives. J. Org. Chem. 1993, 58, 1068-1075.

(44) Substrates $\mathbf{4 a}-\mathbf{d}$ took $3-7$ days for resolution using lipase PS, and substrate 4e took 35 days for complete resolution.

(45) For leading references, see: Littke, A. F.; Schwarz, L.; Fu, G. C. $\mathrm{Pd} / \mathrm{P}\left(\mathrm{t}-\mathrm{Bu}_{3}\right)$ : A Mild and General Catalyst for Stille Reactions of Aryl Chlorides and Aryl Bromides. J. Am. Chem. Soc. 2002, 124 6343-6348, and references cited therein.

(46) Chen, S.-H.; Kadow, J. F.; Farina, V.; Fairchild, C. R.; Johnston, K. A. First Synthesis of Novel Paclitaxel (Taxol) Analogues Modified at the C4-Position. J. Org. Chem. 1994, 59, 6156-6158.

(47) Holton, R. A.; Zhang, Z.; Clarke, P. A.; Nadizadeh, H.; Procter, D. J. Selective Protection of the C(7) and C(10) Hydroxyl Groups in 10-Deacetyl Baccatin III. Tetrahedron Lett. 1998, 39, 2883-2886.

(48) (a) Holton, R. A, Biediger, R. J.; Boatman, P. D. Semisynthesis of Taxol and Taxotere. In Taxol: Science and Application; Suffness, M.; Ed.; CRC Press: New York, 1995; pp 97-121. (b) Georg, G. I.; Boge, T. C.; Cheruvallath, Z. S.; Clowers, J. S.; Harriman, G. C. B.; Hepperle, M.; Park, H. The Medicinal Chemistry of Taxol. In Taxol: Science and Application; Suffness, M., Ed.; CRC Press: New York, 1995; pp 317-375. (c) Ojima, I.; Habus, I.; Zhao, M.; Zucco, M.; Park, Y. H.; Sun, C. M.; Brigaud, T. New and Efficient Approaches to the Semisynthesis of Taxol and its C-13 Side Chain Analogs by Means of $\beta$-Lactam Synthon Method. Tetrahedron 1992, 48, 6985-7012. (d) Ojima, I.; Lin, S.; Chakravarty, S.; Fenoglio, I.; Park, Y. H.; Sun, C-M.; Appendino, G.; Pera, P.; Veith, J. M.; Bernacki, R. J. Syntheses and Structure-Activity Relationships of Novel Nor-seco Taxoids. J. Org. Chem. 1998, 63, 1637-1645.

(49) The reader should note that Phe 272 is the pdb structure code for the Phe 270 sequence code $(\mathrm{F} \beta 270 \mathrm{~V})$ in Table 2.

(50) Wang, M.; Xia, X.; Kim, Y.; Hwang, D.; Jansen, J. M.; Botta, M.; Liotta, D. C.; Snyder, J. P. A Unified and Quantitative Receptor
Model for the Microtubule Binding of Paclitaxel and Epothilone. Org. Lett. 1999, 1, 43-46.

(51) Chaudhary, A. G.; Gharpure, M. M.; Rimoldi, J. M.; Chordia, M. D.; Gunatilaka, A. A. L.; Kingston, D. G. I.; Grover, S.; Lin, C. M.; Hamel, E. Unexpectedly Facile Hydrolysis of the 2-Benzoate Group of Taxol and Synthesis of Analogues With Improved Activities. J. Am. Chem. Soc. 1994, 116, 4097-4098.

(52) (a) Ojima, I.; Kuduk, S. D.; Pera, P.; Veith, J. M.; Bernacki, R. J., Syntheses, and Structure-Activity, Relationships, of Nonaromatic, Taxoids: Effects, of Alkyl, and Alkenyl, Ester, Groups, on Cytotoxicity. J. Med. Chem. 1997, 40, 279-285. (b) Georg, G. I.; Harriman, G. C. B.; Ali, S. M.; Datta, A.; Hepperle, M.; Himes, R. H., Synthesis of 2-O-Heteroaroyl Taxanes: Evaluation of Microtubule Assembly Promotion and Cytotoxicity. Bioorg. Med. Chem. Lett 1995, 5 (2), 115-118. (c) Nicolaou, K. C.; Renaud, J.; Nantermet P. G.; Couladouros, E. A.; Guy, R. K.; Wrasidlo, W. Chemical Synthesis and Biological Evaluation of C-2 Taxoids. J. Am. Chem. Soc. 1995, 117, 2409-2420.

(53) Alcaraz, A. A.; Mehta, A. K.; Snyder, J. P. The T-Taxol Conformation. J. Med. Chem. 2006, 49, 2478-2488.

(54) Giannakakou, P.; Gussio, R.; Nogales, E.; Downing, K. H.; Zaharevitz, D.; Bollbuck, B.; Poy, G.; Sackett, D.; Nicolaou, K. C.; Fojo, T. A common pharmacophore for epothilone and taxanes: Molecular basis for drug resistance conferred by tubulin mutations in human cancer cells. Proc. Natl. Acad. Sci. U.S.A. 2000, 97, 2904-2909.

(55) Giannakakou, P.; Sackett, D.; Kang, Y.-K.; Zhan, Z.; Buters, J. T. M.; Fojo, T.; Poruchynsky, M. S. Paclitaxel-resistant Human Ovarian Cancer Cells have Mutant $\beta$-Tubulins That Exhibit Impaired Palitaxel-driven Polymerization. J. Biol. Chem. 1997, 272, 17118-17125.

(56) Zhou, J.; O'Brate, A.; Zelnak, A.; Giannakakou, P. Survivin Deregulation in $\beta$-Tubulin Mutant Ovarian Cancer Cells Underlies Their Compromised Mitotic Response to Taxol. Cancer Res. 2004, $64,8708-8714$

(57) (a) Nevins, N.; Cicero, D.; Snyder, J. P. A Test of the SingleConformation Hypothesis in the Analysis of NMR Data for Small Polar Molecules: A Force Field Comparison. J. Org. Chem. 1999, 64, 3979-3986. (b) Monteagudo, E.; Cicero, D. O.; Cornett, B.; Myles, D. C.; Snyder, J. P. The Conformations of Discodermolide in DMSO. J. Am. Chem. Soc. 2001, 123, 6929-6930. (c) Thepchatri, P.; Cicero, D. O.; Monteagudo, E.; Ghosh, A. K.; Cornett, B.; Snyder, J. P. Conformations of Laulimalide in DMSO- $d_{6}$. J. Am. Chem. Soc. 2005, 127, 12838-12846.

(58) (a) Friesner, R. A.; Banks, J. L.; Murphy, R. B.; Halgren, T. A.; Klicic, J. J.; Mainz, D. T.; Repasky, M. P.; Knoll, E. H.; Shaw, D. E.; Shelley, M.; Perry, J. K.; Sander, L. C.; Shenkin, P. S. Glide: A New Approach for Rapid, Accurate Docking and Scoring. 1. Method and Assessment of Docking Accuracy. J. Med. Chem. 2004, 47, 1739-1749. (b) Halgren, T. A.; Murphy, R. B.; Friesner, R. A.; Beard, H. S.; Frye, L. L.; Pollard, W. T.; Banks, J. L. Glide: A New Approach for Rapid, Accurate Docking and Scoring. 2. Enrichment Factors in Database Screening. J. Med. Chem. 2004, 47, 1750-1759.

(59) Louie, K. G.; Behrens, B. C,; Kinsella, T. J.; Hamilton, T. C.; Grotzinger, K. R.; McKoy, W. M.; Winker, M. A.; Ozols, R. F. Radiation Survival Parameters of Antineoplastic Drug-sensitive and Resistant Human Ovarian Cancer Cell Lines and Their Modification by Buthionine Sulfoximine. Cancer Res. 1985, 45, 2110-2115.

(60) Chang, M. C.; Uang, B. J.; Wu, H. L.; Lee, J. J.; Hahn, L. J.; Jeng, J. H. Inducing The Cell Cycle Arrest and Apoptosis of Oral KB Carcinoma Cells by Hydroxychavicol: Roles of Glutathione and Reactive Oxygen Species. Br. J. Pharmacol. 2002, 135, 619-630.

(61) (a) Chatterjee, S. K.; Barron, D. M.; Vos, S.; Bane, S. Baccatin III Induces Tubulin to Assemble into Long Microtubules Biochemistry 2001, 40, 6964-6970. (b) Barron, D. M.; Chatterjee, S. K.; Ravindra, R.; Roof, R.; Baloglu, E.; Kingston, D. G. I.; Bane, S. A FluorescenceBased High-Throughput Assay for Antimicrotubule Drugs. Anal. Biochem. 2003, 315, 49-56.

\section{JM061071X}

